\title{
PERAN PAK DALAM GEREJA UNTUK MENANGKAL RADIKALISME DAN FUNDAMENTALISME AGAMA DI KALANGAN GENERASI MUDA
}

\author{
Djoys A. Rantung \\ Universitas Kristen Indonesia \\ djoys.anneke@gmail.com
}

\begin{abstract}
Abstrak
Paham radikalisme dan fundamentalisme agama dewasa ini disebarkan dengan berbagai cara. Di era teknologi informasi seperti sekarang ini paham radikalisme dan fundamentalisme agama lebih cepat tersebar lewat media sosial. Akibatnya, banyak dampak negatif yang ditimbulkan dari penyebaran paham radikalisme dan fundamentalisme agama tersebut. Dampakdampak ini sangat berbahaya bagi bangsa dan juga gereja, terutama generasi muda.

Untuk itu gereja harus mengajarkan kepada generasi muda, mulai dari anak-anak, remaja dan pemuda bagaimana berperilaku hidup sebagaimana yang diajarkan dan diteladankan oleh Tuhan. Tugas-tugas gereja dalam menghadapi bahaya radikalisme dan fundamentalisme agama yang mengancam generasi muda, adalah membangun kehidupan umat beragama yang matang, menghayati spritualitas keugaharian, mampu mengontrol diri, dan berkontribusi dalam mengusahakan keadilan, kesetaraan dan kemanusiaan. Dalam hal ini, Yesus menjadi role model dalam radikalisme perdamaian, yakni cinta kasih, keadilan, kesetaraan dan kemanusiaan memiliki pengaruh pada generasi muda berupa perkembangan sifat destruktif dan keras, hilangnya rasa cinta tanah air, rusaknya pemikiran kaum muda, munculnya paradigma yang salah, dan memicu pemikiran yang kritis. Di Indonesia sendiri, radikalisme sudah menjalar ke berbagai lapisan masyarakat dan sudah menjalar ke berbagai sektor kehidupan masyarakat Indonesia dan siap untuk menghancurkan kedaulatan Negara Kesatuan Republik Indonesia. Bahaya radikalisme fundamentalisme agama sangat mengancam generasi muda. Karena, generasi muda adalah harapan dan penerus bangsa dan gereja.

Banyak cara paham radikalisme fundamentalisme disebarkan, terutama di era teknologi ini yakni lewat internet dan media sosial. Dampak negatif banyak yang ditimbulkan dari penyebaran paham radikalisme tersebut. Dampak-dampak ini sangat berbahaya bagi bangsa dan juga gereja, terutama generasi muda. Gereja memiliki peran yang penting bersama dengan pemerintah untuk menjaga stabilitas, keamanan dan juga perdamaian.

Model penelitian yang digunakan dalam penelitian ini adalah kualitatif, berdasarkan hasil studi pustaka berbagai sumber, yaitu sejumlah literatur berbahasa Indonesia dan Inggris dalam meneliti peran PAK dalam gereja untuk menangkal radikalisme dan fundamentalisme agama di kalangan generasi muda. Metode pengumpulan data yang digunakan adalah kualitatif deskriptif. Hasil penelitian ini didapati bahwa radikalisme dan fundamentalisme agama adalah gerakan agama yang berupaya merombak secara total suatu suasana sosial atau tatanan politis yang ada dengan menggunakan kekerasan. Faktor-faktor yang mempengaruhi munculnya paham ini, adalah nasionalisme, agama, globalisasi, pemikiran, ekonomi, (kemiskinan dan kesenjangan), kekuasaan politis dan lemahnya negara, kurangnya kesadaran hidup sesuai Pancasila, sosial, ideologi, psikologis dan pendidikan. Peran PAK dalam gereja untuk menangkal radikalisme dan fundamentalisme agama di kalangan generasi muda, adalah melakukan perintah Tuhan dalam hukum kasih, yakni kebaikan, keadilan dan damai sejahtera atau shalom. Gereja sebagai salah satu pelaku PAK berkewajiban untuk melakukan program bersama pemerintah yakni softderadikalisasi. Peran PAK dalam gereja dapat diwujudkan dalam kurikulum-kurikulum dengan metode dan materi pendidikan, pengajaran dan pembinaan tentang iman Kristen dengan nilai-nilai kasih, kebaikan, keadilan dan damai sejahtera serta kurikulum pendidikan religius lintas iman di kalangan orang
\end{abstract}


Shanan Jurnal Pendidikan Agama Kristen Vol. 2 No. 1 Maret $2018 \mid 2$

muda atau generasi muda untuk saling belajar mengenal agama satu dengan yang lainnya, sebagai tindakan untuk mencegah radikalisme dan fundamentalisme agama.

Kata Kunci: Radikalisme, Fundamentalisme, Gereja, PAK, Generasi Muda. 


\section{Pendahuluan}

Radikalisme dan fundamentalisme agama di Indonesia telah menjadi fakta yang tidak bisa diabaikan ataupun dihilangkan. Radikalisme dan fundamentalisme keagamaan yang semakin meningkat di Indonesia ini ditandai dengan berbagai aksi kekerasan dan teror. Aksi tersebut telah menyedot banyak potensi dan energi kemanusiaan serta telah merenggut hak hidup orang banyak termasuk orang yang sama sekali tidak mengerti mengenai permasalahan ini.

Meski berbagai seminar dan dialog untuk mencari sebab hingga sampai pada penawaran solusi, namun hingga kini tidak juga adanya suatu titik terang yang menandakan paham radikalisme dan fundamentalisme agama di Indonesia makin melemah. Justru radikalisme terus berkembang dengan aksi-aksi terror, bom bunuh diri dan berbagai aksi yang tidak dapat diprediksi kapan datangnya. Para penggerak radikalisme akan selalu berusaha menciptakan bentuk-bentuk baru, papan nama baru, busana baru, bendera baru, dengan berbagai cara mereka lakukan.

Saat ini, paham radikalisme kian menanjak ditengah dinamika kehidupan masyarakat. Bahkan ada yang menilai kasus radikalisme di Indonesia makin kronis, yakni sudah memasuki kategori merah atau sangat membahayakan. Paham ini umumnya menyebar melalui dakwah-dakwah yang dilakukan di rumah-rumah ibadah, pengajian, dan lembaga pendidikan. ${ }^{1}$ Paham Radikalisme merupakan salah satu ancaman nyata terhadap kehidupan dunia global.

\footnotetext{
${ }^{1}$ Endang Turmudzi dkk, Islam dan Radikalisme di Indonesia (Jakarta: LIPI Pres, 2004), 5.
}

Dampak dari makin kuatnya radikalisme dan fundamentalisme agama dapat berimplikasi luas yakni menimbulkan guncangan ekonomi dan politik yang tidak kecil, sehingga menciptakan rasa tidak aman pada masyarakat luas. Karena itu, gereja harus berperan penting dalam pengajaran, pembinaan dalam pokok-pokok pengajaran terutama dalam Pendidikan Agama Kristen kepada segala usia terutama kepada anak-anak muda sebagai generasi muda.

Sebab generasi muda adalah generasi penerus bangsa dan gereja. Generasi muda harus memperhatikan segala bentuk bahaya, ancaman dan faktor-faktor yang mempengaruhi seseorang bisa terpengaruh dengan berbagai ajaran atau doktrin yang mengarah pada kesesatan apalagi doktrin radikalisme fundamentalisme garis keras, yakni dengan cara berjihad atau berperang apalagi bom bunuh diri.

Gereja bersama semua orang Kristen, tidak boleh berhenti untuk memperjuangkan dan membela keadilan, kasih dan kebenaran bagi siapapun. Bukan saja kepada saudaranya yang gerejanya ditutup oleh kelompok-kelompok radikalisme, tetapi kepada semua orang. Gereja dan Orang Kristen harus berjuang atas nama keadilan untuk siapapun di Indonesia ini. ${ }^{2}$ Tugas Gereja adalah menghancurkan sekat-sekat pemisah di antara sesama gereja dan berusaha membangun jejaring baik di kalangan sesama Gereja atau sesama umat maupun dengan umat dari agama lainnya serta dengan semua kelompok dan masyarakat yang peduli dan memperjuangkan persamaan hak (equality), kebebasan

\footnotetext{
2 http://www.leimena.org/id/page/v/8/institutleimena diunduh pada 22 April 2018
} 
(liberty), dan persaudaraan (fraternity). ${ }^{3}$ Gereja berperan dengan sungguhsungguh dan tulus membangun kesadarannya dan umat Kristen bahwa keseriusan dengan iman Kristen sama berartinya dengan menyadari dan menghargai pluralitas negeri ini dan sama berharganya dengan upaya menegakkan keadilan, menyatakan kepedulian kepada orang miskin, dan sama berartinya dengan memperjuangan keadilan, kebenaran dan cinta kasih. ${ }^{4}$

Tugas gereja dalam pengajaran Pendidikan Agama Kristen bagi generasi muda adalah dengan metode, kurikulum dan isi pengajaran yang berdasarkan pengajaran dan keteladanan Yesus dalam iman Kristen. Mengajarkan cinta kasih dan perdamaian untuk semua orang.

Adapun maksud dan tujuan penelitian ini adalah untuk mengetahui paham radikalisme dan fundamentalisme dalam agama, apa faktor-faktor yang mempengaruhinya, dan bagaimana ciriciri gerakan radikal. Apa pandangan Alkitab terhadap bahaya radikalisme dan fundamentalisme dan bagaimana peran gereja dalam PAK menghadapi bahaya radikalisme dan fundamentalisme yang mengancam generasi muda. Pendekatan yang dipakai dalam penelitian ini adalah pendekatan penelitian kualitatif deskriptif dengan studi pustaka.

\section{Pengertian Radikalisme- Fundamentalisme}

Kata 'radikalisme' berasal dari kata 'radikal', dan 'radikal' berasal dari bahasa Latin 'radix' yang memiliki arti

\footnotetext{
${ }^{3}$ http://m.satuharapan.com/index.php?id=148\&tx ttnews[tt_news) diunduh pada 22 April 2018.

${ }^{4}$ Weinata Sairin, Visi Gereja Memasuki Milenium Baru (Jakarta: BPK-Gunung Mulia 2002), 67-68.
}

akar. Dalam Dictionary of Current English kata radikal diartikan sebagai ekstrem atau bergaris keras. Radikalisme berarti satu paham aliran yang menghendaki perubahan secara drastis. ${ }^{5}$ Dalam Kamus Umum Bahasa Indonesia radikal artinya sampai ke akar-akarnya, paham atau haluan politik yang menginginkan (menuntut) perubahan atau pembaharuan sosial dan politik dengan cara keras. ${ }^{6}$ Dalam Ensiklopedi Indonesia disebutkan radikalisme adalah semua aliran politik yang para pengikutnya menghendaki konsekuensi ekstrem, setidaknya konsekuensi yang paling jauh dari perwujudan ideologi yang mereka anut. ${ }^{7}$

Radikalisme adalah paham atau aliran secara mendasar dan prinsip yang radikal dalam kehidupan politik. Ini adalah suatu konsep atau semangat yang berupaya untuk mengadakan perubahan kehidupan politik secara menyeluruh dan mendasar tanpa memperhitungkan adanya ketentuan-ketentuan konstitusi-onal, politis dan sosial. ${ }^{8}$ Dari pengertian di atas dapat disimpulkan bahwa radikalsime adalah suatu paham yang menghendaki perubahan mendasar dengan kecenderungan menggunakan kekerasan. Paham ini sebenarnya paham politik yang menghendaki perubahan yang ekstrem, sesuai dengan pengejawantahan ideologi yang mereka anut.

\footnotetext{
${ }^{5}$ H.S.Hornby, Oxford Advanced: Dictionary of Current English (Britain: Oxford University Press), 691.

${ }^{6}$ Kamus Besar Bahasa Indonesia, (Jakarta: Ikhtiar Baru, 1995), 354.

7 Van Hoeve, Ensiklopedi Indonesia, (Jakarta: Ikhtiar Baru, 1984), 76.

${ }^{8}$ Adnon Nasrullah Jamaludin, Agama dan Konflik Sosial (studi kerukunan umat beragama, radikalisme dan konflik antar umat beragama), (Bandung: Pustaka Setia, 2015), 160-162.
} 
Radikalisme selalu berhubungan dengan fundamentalisme yang berarti dasar. Dengan demikian, radikalismefundamentalisme berhubungan dengan cita-cita yang harus diperjuangkan, orang harus kembali ke asas dasar dari suatu ajaran. Persoalan radikalisme agama memang akan mencakup persoalan yang cukup kompleks karena mencakup berbagai dimensi kehidupan, seperti keyakinan, interpretasi ajaran, lingkungan sosial, tradisi budaya, tingkat keimanan umat, dan pemahaman terhadap setiap perubahan yang terjadi.

Fundamentalisme pada umumnya dipahami sebagai suatu paham atau ide. Secara terminologi kata Fundamentalisme berasal kata kerja kerja fundare, yang berarti mendasarkan, suatu paham, fundamentalisme merupakan sebuah paham atau ide yang mengalaskan, menegakkan dasar atau memegang pendirian yang mendasar, kemudian kata fundus berarti 'alas' atau 'dasar'. ${ }^{9}$ Dengan demikian fundamental sebagai dasar untuk menggerakkan suatu tindakan, kegiatan, tindakan, aktivitas untuk mendasarkan, menegakkan atau memegang teguh pendirian fundamental. Sedangkan orang yang menganut paham atau yang melakukan tindakan-tindakan penegakkan dasar atau ajaran funda-mental disebut sebagai fundamentalis.

Dalam bahasa Italia, Jerman dan Perancis, kata fundamentalisme disebut dengan integralisme. Pada dasarnya kata ini tidak identik sama karena kata integralisme kerap dikenakan dalam kosa kata politik namun ada terkandung pemaknaan yang cukup dekat di antara ke duanya. Integralisme (dari bahasa Latin

\footnotetext{
9 Armada Riyanto, Membongkar Eksklusivisme Beragama” dalam Agama-Kekerasan, Membongkar Eksklusivisme (Malang : Dioma, 2000), 18 .
}

integer) diartikan keutuhan, kesempurnaan, kebulatan dan kemurnian. Dalam konteks keagamaan, integralisme adalah paham dalam hidup beragama yang berhubungan dengan aktivitas-aktivitas untuk menegakan keutuhan, kemurnian dan kesempurnaan ajaran iman. Dalam kata kerja, kata ini menjadi integralismus yang menunjuk pada konsep mengenai perjuangan untuk membela integritas, kesatuan, keutuhan, antara agama dan politik. Radikalisme-fundamentalisme agama merupakan gerakan agama yang berupaya merombak secara total suatu tatanan sosial atau tatanan politis yang ada dengan menggemakan kekerasan. Radikalisme sering dihubungkan dengan adanya pertentangan yang tajam menyebabkan konsep radikalisme selalu dikaitkan dengan sikap dan tindakan yang radikal, yang kemudian dikonotasikan dengan kekerasan secara fisik.

\section{Menurut Yusuf Qardhawi 10} radikalisme agama atau at-tatharuf addiniy secara etimologis berarti "berdiri di ujung, jauh dari pertengahan". Dapat pula diartikan berlebih dalam sesuatu. Lebih lanjut, ia mengemukakan bahwa pada awalnya kata tersebut digunakan untuk hal-hal yang konkret, seperti berlebihan dalam berdiri, duduk dan berjalan. Kemudian, penggunaannya dialihkan untuk hal-hal yang bersifat abstrak, seperti berlebihan dalam beragama, berpikir dan berperilaku. Dalam bahasa Arab, istilah radikalisme biasa disebut tathorruf lalu menjadi muthothorifin. Kemudian diartikan dengan istilah teror atau menciptakan bencana. Dominasi ini melahirkan berbagai macam fanatisme, mulai yang paling lunak sampai yang paling berat. Paham yang paling berat

\footnotetext{
10 Yusuf Qardhawi, Islam Radikal: Analisis terhadap Radikalisme dalam berislam dan upaya pemecahannya (Solo: Era Intermedia, 2000),13.
} 
adalah Hizbul Takfiriyyah, yaitu kelompok yang selalu mengatakan bahwa golongan diluar dirinya adalah kafir.

Paham fundamentalis ini akan berusaha atau bertindak dalam menegakkan ajaran-ajaran yang mendasar, fundamental, asli, mendasar, otentik, harfiah membuat mereka menolak atau menendang yang lainnya untuk mendapatkan tujuan. Penolakan yang mereka lakukan tidak jarang membuat mereka menjadi intoleran dan melakukan kekerasan.

Fundamentalisme agama berarti keyakinan akan adanya satu keagamaan tertentu yang mengandung hal fundamental, mendasar, hakiki, kebenaran yang sempurna mengenai manusia dan ilahiah; kebenaran yang hakiki ini tengah diserang oleh kekuatan iblis dan perlu diperjuangkan dengan kekuatan penuh; hal yang hakiki dan fundamental ini harus diikuti dan tidak berubah sejak dari masa lalu; dan setiap orang yang percaya dan mengikuti keyakinan akan ajaran yang hakiki ini memiliki hubungan yang khusus dengan Allah. Sebagaimana yang dikutip Rakhmat dari pandangan Altemeyer dan Hunsberg ${ }^{11}$, yakni "the belief there is one set religious that clearly contains the fundamental, basic, intrinsic, essensial, innerant truth about humanity dan deity; that this essential truth of fundamentally opposed by forced of evil which must be vigourously fought; that this must be followed today according to the fundamental, unchangeable practice of the past; and that those who believe and follow these fundamental teaching have a special relationship with the deity."

11 Jalaludin Rakhmat, Islam dan Pluralisme (Jakarta : Serambi, 2006), 169
Dari pengertian di atas dengan jelas dapat memberikan gambaran bahwa fundamentalisme agama, yaitu: (1) keyakinan akan kebenaran mutlak agama, (2) adanya pertarungan antara kebenaran mutlak ini dengan kekuatan jahat, (3) dasar agama ini mutlak dan tidak berubah, (4) hubungan istimewa antara sekelompok "elite" umat manusia dengan Allah.

\section{Radikalisme dan Fundamentalisme dalam Agama}

Radikalisme keagamaan sebenarnya fenomena yang biasa muncul dalam agama apa saja. Radikalisme sangat berkaitan erat dengan fundamentalisme, yang ditandai oleh kembalinya masyarakat kepada dasar-dasar agama. Fundamentalisme adalah semacam Ideologi yang menjadikan agama sebagai pegangan hidup oleh masyarakat maupun individu. Biasanya fundamentalisme akan diiringi oleh radikalisme dan kekerasan ketika kebebasan untuk kembali kepada agama tadi dihalangi oleh situasi sosial politik yang mengelilingi masyarakat.

Radikalisme yang muncul dalam kehidupan umat beragama merupakan model pikiran dan tindakan dengan dasar penolakan terhadap bentuk budaya dan nilai-nilai dari luar agamanya. ${ }^{12}$ Karena itu para pelaku radikalisme biasanya hanya mengambil poin pandangan tertentu dari agama yang dianutnya. Pandangan tersebut kemudian dititikberatkan untuk mendukung sikap, tindakan, dan pendirian yang mereka anut. ${ }^{13}$ Ketidakmampuan seseorang

\footnotetext{
${ }^{12}$ Sivan E, Friedman M, ed., Religious radicalism and politics in the Middle East (New York: State University of New York, 1990), 42.

${ }^{13}$ Hood, Hill, Spilka B., Op.Cit., 20.
} 
dalam memahami agamanya secara utuh dan bertanggung jawab itulah yang diduga telah menjadi salah satu katalisator timbulnya paham dan perilaku radikalisme dana diri seseorang. Radikalisme juga dapat terjadi karena pengikut agama yang kemudian menjadi radikalis tidak atau kurang memahami agama dan ajaran agamanya sendiri. Kekurangpahaman juga dapat terjadi ada motivasi dan dasar yang di-gunakan dalam gerakan. ${ }^{14}$

Ketiga agama Abrahamik, yaitu Yahudi, Kristen, dan Islam memiliki bukti-bukti nyata dan eksplisit mengenai radikalisme, sehingga jelas bahwa radikalisme tidak terbatas pada agama tertentu. ${ }^{15}$ Di kalangan agama-agama lain juga punya paham radikalisme. Seperti halnya dalam agama Hindu, Budha, Kristen dan Islam, seperti berikut: ${ }^{16}$

Pertama, Radikalisme agama Hindu muncul ketika kalangan Hindu merespon penjajahan Inggris yang menguasai India. Respon itu memunculkan gerakan Bajrangdal, Rashtriya Svayam Sevak (RSS). Dalam konteks yang lain, radikalisme muncul dengan sosok Mahatma Ghandi. Ia tokoh radikal dalam tata pikir, namun santun dalam tindakan. Pemahaman agama Hindunya sangat mendalam dan mampu merealisasikannya sehingga ia dikenal dengan sosok yang humanis. Walaupun pada akhirnya ia meninggal karena ditembak mati oleh kelompok RSS, demikian pula ditembaknya Indira Ghandi, ia ditembak oleh pengawal kelompok Sikh dan terakhir dibunuhnya Rajiv Ghandi karena bom

\footnotetext{
${ }^{14}$ Tetreault MA, Denemark RA, ed., Gods, guns \& globalization: religious radicalism \& international political economy (Colorado: Lynne Rienner Publishers, 2004), 65.

${ }^{15}$ https://epthinktank.eu/2016/07/12/radicalisationextremism-and-terrorism-words-matter/ diunduh pada 21 April 2018.

${ }^{16}$ Ibid.
}

bunuh diri yang dilakukan oleh kelompok garis keras Hindu yaitu Elam Tamil.

Kedua, Radikalisme dalam agama Buddha muncul pada masa dinasti Sungga berkuasa. Setelah mereka membunuh raja Bratadatha, maka hulubalang Pusyamitra Sungga naik tahta, ia seorang ortodox yang dikenal dengan kebencian dan penindasannya terhadap para biksu. Ia merusak wihara dan membunuh para biksu dengan imbalan 100 keping koin emas untuk setiap kepala biksu yang bertentangan dengan dirinya.

Ketiga, Radikalisme dalam agama Kristen muncul pada abad XVI, dengan adanya reformasi yang dilakukan oleh kelompok Protestan. Reformasi tersebut memunculkan Gereja-gereja Protestan. Sehingga perpecahan tersebut merupakan awal mula atau benih munculnya radikalisme dalam agama Kristen. Tokohnya adalah seorang Marthin Luther King yang dianggap sebagai kaum radikalis oleh kelompok Katholik, Marthin dianggap mampu melakukan perubahan dalam struktur gereja baik secara fisik maupun ajaran keagamaannya.

Keempat, Radikalisme dalam agama Yahudi, munculnya radikalisme ketika terjadi pertentangan antara Yahudi orthodox dan Yahudi orthodox ekstrim. Kaum Yahudi orthodox menerima paham zionisme dan konsep Negara Israel. Mereka berpandangan bahwa untuk membangun Negara Israel raya tidak perlu menunggu kedatangan seorang nabi, namun cukup dengan bekerja keras dalam membangun negara Israel. Sementara kelompok Yahudi orthodox ekstrim menyangkal anggapan ini. Mereka menolak paham zionisme dan konsep Negara Israel. Menurut kelompok garis keras ini tidak boleh mendahului takdir Tuhan karena Tuhan akan mengirimkan nabi yang akan membangun Negara Israel raya. Yahudi ini sangat 
ekstrim, radikal, dan rasis seperti Baruch Goldstein yang membantai umat Islam yang sedang sholat subuh pada tahun 1994. Seorang Yigal Amir yang membunuh PM Yitzhak Rabin karena ia katanya diperintah oleh Tuhan. Dua kelompok Yahudi tersebut melakukan penjajahan atas warga Palestina.

Kelima, Radikalisme agama Islam ektrim muncul pertama kalinya pada masa pemerintahan Ustam bin Afan, dalam bentuk gerakan yang dipimpin oleh Abdulah bin Saba' bersama dua ribu pengikutnya yang menghendaki untuk digantinya Usman bin Afan dari kedudukannya sebagai khalifah dengan Ali bin Abi Tholib. Karena mereka beranggapan bahwa Ali bin Tholib lebih dekat hubungan kekeluargaannya dengan Nabi Mahammad SAW, dibanding dengan Ustman. Kelompok Abdullah bin Saba' berhasil membunuh Khalifah Ustman bin Afan, dan Negara dalam keadaan kacau, sehingga para sahabat nabi mendesak Ali bin Abi Tholib untuk memangku jabatan khalifah untuk menghindari kehancuran Negara. Bahkan dalam sejarah gerakan radikalisme pada masa Ali semakin berkembang dengan munculnya gerakan radikal ekstrim Ibnu Saba' yang menganggap Ali dan anak cucunya sebagai titisan Tuhan. Pada masa itu pula teror dan kekacauan terjadi.

Salah satu hasil nyata yang dapat terlihat dari radikalisme adalah terorisme. Terorisme adalah "penggunaan kekerasan untuk menimbulkan ketakutan dalam usaha mencapai tujuan (terutama tujuan politik); praktik tindakan teror." 17 Terorisme saat ini lebih banyak muncul dengan motif agama walaupun sejak dulu sudah ada dan lebih banyak bermotif

\footnotetext{
${ }^{17}$ Kamus besar bahasa Indonesia Edisi kelima. (Jakarta: Kementerian Pendidikan dan Kebudayaan Republik Indonesia, 2016), 85.
}

nasionalis. ${ }^{18}$ Terorisme yang didasarkan atas agama bersifat kuat karena didasari oleh motivasi loyalitas terhadap Tuhan. Pembedaan antara pengikut dan non pengikut yang tercantum dalam ajaran berbagai agama juga berperan dalam menguatkan motivasi ini. Motivasi lain yang mendasari terorisme adalah keinginan untuk menjadi martir bagi agamanya. ${ }^{19}$

\section{Faktor-Faktor yang Mempengaruhi}

Ada banyak faktor yang memberikan pengaruh munculnya paham radikalisme-fundamentalisme. Di Indonesia, hal radikalisme-fundamentalisme sering muncul akibat faktor: rasa nasionalisme, agama, globalisasi, pemikiran, ekonomi (kemiskinan dan kesenjangan), kekuasaan politis dan lemahnya negara, penyalahgunaan agama oleh oknum yang tidak bertanggung jawab, kurangnya kesadaran hidup sesuai Pancasila, sosial, ideologi, psikologis, pendidikan, dan lain sebagainya. Berikut ini penjelasan tentang faktor-faktor di atas:

\section{Faktor Nasionalisme}

Radikalisme yang didorong oleh faktor nasionalisme biasanya terjadi di negara atau wilayah yang masih ada dalam alam penjajahan dan rakyatnya menilai bahwa sistem pertahanan yang berlaku adalah sangat kejam, tidak adil, dan berpendapat bahwa jalan lain selain radikalisme tidak mungkin untuk me-

\footnotetext{
18 Timmerman, ed., Faith-based radicalism: Christianity, Islam, and Judaism between Constructive Activism and Destructive Fanaticism (Brussels: Peter Lang, 2007), 65.

${ }^{19} \mathrm{http} / / /$ nasional.kompas.com/read/2017/03/15/14 090061/bin.menguatnya.kelompok.radikal.keaga maan.jadi.penyebab.konflik.sosial diunduh pada 21 April 2018.
} 
ngubah kehidupan mereka menjadi lebih baik. Dimotori oleh sekelompok radikal, terjadilah perlawanan rakyat terhadap pihak penguasa, dengan berbagai sarana dan cara yang ada, untuk mengharapkan pergantian pemerintahan atau mendapatkan kedudukan. ${ }^{20}$

\section{Faktor Agama}

Radikalisme yang didorong oleh faktor agama biasanya mendasarkan aksiaksinya berdasarkan ketentuan dalam agama itu sendiri yang oleh masyarakat luas diinterpretasikan berbeda-beda. Sebagian dari masyarakat di negaranegara Islam berpendapat bahwa agama Islam adalah suatu agama yang menghendaki perdamaian. Akan tetapi, ada golongan yang memberikan interpretasi bahwa ada ketentuan yang dalam agama bersangkutan menyebutkan bahwa segala perbuatan yang tidak diizinkan (diridoi) oleh agama tersebut dilarang. Dalam masyarakat juga terdapat penilaian bahwa segala keadaan di masyarakat yang bertentangan dengan norma-norma agama yang dianut perlu dihilangkan atau diupayakan untuk diberantas dengan segala cara. $^{21}$

\section{Faktor Globalisasi}

Tidak ada yang niscaya pada globalisasi dalam coraknya selama 25-30 tahun terakhir. Asal-muasal corak globalisasi dewasa ini dengan pelatuk ekonomi-politiknya di paroh kedua dasawarsa 1970-an sudah banyak ditunjukkan. Apa yang relevan: optimisme the end of history tentang kapitalisme dan demokrasi liberal sebagai bentuk akhir sejarah (cf. Fukuyama) bahkan ditertawa-

\footnotetext{
${ }^{20}$ Adnon Nasrullah Jamaludin, Op.Cit., 163

${ }^{21}$ Ibid, 163-164.
}

kan sejak awal, dan gelombang-balik beberapa tahun terakhir ini mengisyaratkan ciri terbuka sejarah.

Tiga penggerak globalisasi dalam cirinya 25-30 terakhir terletak pada mobilitas global (a) barang, (b) modalgagasan, (c) orang. Aneka ledakan antiglobalisasi juga terarah pada 3 perkara itu, tentu dengan kadar berbeda-beda. Terutama mobilitas 'orang' dalam lonjakan migrasi (entah migrasi terpaksa karena perang atau migrasi ekonomi demi perbaikan income) menjadi faktor besar dalam backlash, dalam rupa rasa-merasa terancam entah terkait lapangan kerja ataupun suasana kultural. Tentu faktor 'orang' (migrasi) ini tidak terpisahkan dari aneka faktor kesenjangan karena kinerja 'modal dan ide' (financial and knowledge capitals). Penelitian tentang pokok ini cukup kompleks. Misalnya, mobilitas modal dalam bentuk FDI (foreign direct investment) dilihat lebih membawa berkah, sedangkan transaksi short-term perbankan cross-border lebih membawa kutuk. Lonjakan radikalismefundamentalisme agama merupakan bagian dari gelombang global populisme, yaitu paham tentang realitas politik yang berupa oposisi diametral antara 'rakyat' dan 'elite', dan agenda populis berisi penjungkirbalikan jaringan-jaringan institusional yang dilihat mengemban kepentingan persekongkolan kaum elite untuk mengkangkangi rakyat. Populisme ini melanda dunia dalam bentuk populisme agama, populisme etnis/ras, populisme kelas, populisme kebangsaan, populisme peradaban, dsb. Populisme ini membuyarkan spektrum ideologi lama 'kiri' (sosialis) dan 'kanan' (konservatif), dan sebagai gantinya menyuntikkan spektrum ideologis baru dalam oposisi 'tertutup' (shut) dan 'terbuka' (open). Itulah mengapa populisme terkena baik pada partai-partai kiri (left) seperti 
Podemos di Spanyol atau Syriza di Yunani maupun partai-partai kanan (right) seperti Freedom Party di Austria atau National Front di Prancis. Populisme kelas sosial (e.g., Yunani, Spanyol): dipicu oleh krisis ekonomi. Populisme kebangsaan: (e.g., Perancis, Polandia, Hungaria): dipicu persoalan migrasi, bukan oleh krisis ekonomi. Populisme superioritas ras kulit putih (e.g., AS dengan kemenangan Donald Trump). Populisme peradaban dan ras (e.g., China): ideologi triumfalis naiknya China jadi superpower; juga Rusia di bawah Putin. Populisme nativisme-agama (e.g., India): Hindutva sebagai doktrin kesamasebangun-an Hindu dan India; juga nativisme-agama Buddhis di Myanmar, Sri Lanka. Populisme agama (Indonesia): terutama menandai kelompok-kelompok Islam garis keras. ${ }^{22}$

Globalisasi dalam hubungan ini adalah dampak dari kemajuan teknologi di negara-negara maju yang hasilnya menyalur ke pelosok dunia. Negaranegara penerima yang pada umumnya adalah negara berkembang belum tentu siap dengan kemajuan teknologi tersebut. $^{23}$

\section{Faktor Pemikiran}

Merebaknya dua trend paham yang ada dalam masyarakat Islam, yang pertama menganggap bahwa agama merupakan penyebab kemunduran umat Islam. Sehingga jika umat ingin unggul dalam mengejar ketertinggalannya maka ia harus melepaskan baju agama yang ia miliki saat ini. Pemikiran ini merupakan produk sekularisme yang secara pilosofi

\footnotetext{
${ }^{22}$ Herry Priyono, Op.Cit, 4-5.

${ }^{23}$ Ermaya Suradinata, Seri Seminar Masa Depan Bangsa dan Radikalisme Agama (Bandung: Gunung Djati Press, 2006), 1.
}

anti terhadap agama. Sedang pemikiran yang kedua adalah mereflesikan penentangannya terhadap alam relaitas yang dianggapnya sudah tidak dapat ditolerir lagi, dunia saat ini dipandanganya tidak lagi akan mendatangkan keberkahan dari Allah, penuh dengan kenistaan, sehingga satu-satunya jalan selamat hanyalah kembali kepada agama. Namun jalan menuju kepada agama itu dilakukan dengan cara-cara yang sempit, keras, kaku dan memusuhi segala hal yang berbau modernitas. Pemikiran ini merupakan anak kandung dari pada paham fundamentalisme. ${ }^{24}$

\section{Faktor Ekonomi (Kemiskinan dan Kesenjangan)}

Apa yang dimaksud istilah 'ekonomi' di sini menunjuk pada gejala yang terkait dengan kegiatan pemenuhan kebutuhan hidup (organisation of human livelihood): proses produksi, alokasi, transaksi pertukaran, dan gejala-gejala yang terbentuk dari proses itu, seperti neraca perdagangan, lapangan kerja, pengangguran, ketimpangan pendapatan, dan sebagainya.

Ada pendapat bahwa faktor ekonomi merupakan motif utama bagi para terorisme dalam menjalankan misi mereka. Keadaan yang semakin tidak menentu dan kehidupan sehari-hari yang membuat resah orang untuk melakukan apa saja. Dengan seperti ini pemerintah harus bekerja keras untuk merumuskan rehabilitasi masyarakatnya. Kemiskinan membuat orang gerah untuk berbuat yang tidak selayaknya diperbuat seperti; membunuh, mengancam orang, bunuh diri, dan sebagainya. ${ }^{25}$

\footnotetext{
${ }^{24}$ Adnon Nasrullah Jamaludin, Op.Cit., 163.

${ }^{25}$ Ibid, 163-164.
} 
Menurut Herry Priyono, apakah faktor ekonomi penyebab utama? Ini bukan pertanyaan teoretik. Jawabannya tidak terletak pada tataran konseptual tapi pada dataran pola empirik. Apa yang biasa dipelajari dari pelatihan analisis social-yaitu metode mencari "penyebab akar" (root cause), warisan pertanyaan filsafat "prinsip pertama" (first principle)-tentulah baik sebagai latihan, tapi terjadinya gejala riil lebih dari sakadar karena root cause. Dan pemisahan bidang-bidang seperti ekonomi, politik, budaya, hukum, dan sebagainya yang diciptakan dunia pemikiran dan pembagian kerja akademik juga baik saja sebagai disiplin metodis analisis, tapi penyebab riil gejala jauh melampaui spesialisasi teropong-metodis itu. $^{26}$

Beberapa peneliti lain melihat kaitan radikalisme-fundamentalisme dan kemiskinan/ketimpangan itu terjadi tidak langsung. Faktor yang lebih kuat menjadi penanda gejala radikalisme-fundamentalisme adalah "negara lemah dan negara gagal" (weak and failed states). Jadi, tingkat rendah/amat rendah fungsi negara dalam pelayanan publik (termasuk dalam hal ekonomi) menjamurnya kemiskinan dan ketimpangan mudahnya kaum ekstremis agama merekrut pengikut. Faktor ekonomi (seperti kemiskinan dan ketimpangan) dapat menjadi salah satu pra-kondisi bagi suburnya radikalisme-fundamentalisme agama, tetapi kaitan tidak langsung seperti anggapan umum. Setelah mencermati data dari berbagai negara, majalah The Economist bahkan punya ungkapan "It's not the economy, stupid!" untuk menunjuk faktor penyebab melonjaknya gejala partai-partai sayap kanan. Di sini kita juga perlu hati-hati,

\footnotetext{
${ }^{26}$ Herry Priyono, Op.Cit., 1.
}

sebab kaum radikal-fundamentalis persis suka memakai faktor ekonomi ini sebagai idiom mobilisasi sentimen massa bagi ambisi politik mereka. Bahkan munculnya ISIS dan motif para pen-dukungnya tak bisa dikatakan pertama-tama digerakkan oleh faktor ekonomi. ${ }^{27}$

Faktor ekonomi (proxy: kemiskinan dan kesenjangan) penting sebagai prakondisi, tetapi factor ini bukan menjadi pemicu kausal secara langsung seperti yang dikesankan pada khalayak. Seperti telah disebut, kemiskinan dan ketimpangan tentu kondisi yang subur bagi rekrutmen rasa-merasa tak berdaya (powerless) bagi mobilisasi sentimen populis apapun, entah melalui jalur paham ekstrem atau pembelian kehadiran dalam mobilisasi massa. Namun klaim faktor ekonomi sebagai penyebab perlu dipahami dengan hati-hati, sebab kaum radikal-fundamentalis persis memproyeksikan secara publik faktor ekonomi sebagai penyebab terpenting.

\section{Faktor Kekuasaan Politis dan lemahnya Negara $^{28}$}

Pertarungan kekuasaan politik di suatu negara (entah lewat proses elektoral atau bukan), corak sentimen identitas yang siap dipakai untuk menyatukan emosi politik, dan lemah atau gagalnya institusi negara hadir dalam pelayananpelayanan publik. Seperti disebut, di kawasan tertentu sentimen itu berupa kelas sosial (Yunani, Spanyol), di kawasan lain sentimen itu superioritas ras (AS, China), di daerah lain lagi rasagama (India) atau agama (Indonesia).

\footnotetext{
${ }^{27}$ Ibid, 4-6.

${ }^{28}$ Ibid, 6-9.
} 
Dalam radikalisme-fundamentalisme agama, nampak bahwa soal utama bukan agama atau teologi, tetapi sentimen agama di negara tertentu merupakan sentimen yang paling cepat dipakai untuk menggerakkan/menyatukan emosi politik. Tentu saja, mobilisasi sentimen agama butuh legitimasi teologis, tetapi makin jelas bahwa faham teologis ini lebih merupakan "ilusi pembenaran" ketimbang sebagai dasar gerakan.

Ada ambisi dari para politikal (political entrepreneurs), pebisnis dan agamawan untuk meraih ataupun mengambil alih kekuasaan politik. Sentimen agama adalah cara paling cepat untuk mobilisasi sentimen demi ambisi politik tersebut, dengan memanasi sentimen kebencian dan memakai 'ketakutan' serta ciri tremendum sebagai daya tariknya. Di sini terjadi konvergensi antara para pemain politik, pendana mobilisasi massa, pemimpin ormasormas, para pemain faham teologis/keagamaan fundamentalis, dan kerinduan sentimen tribal. Inilah konvergensi faktor ideologis, politik, ekonomi, sosial, kultural, hukum, dan seerusnyat. Apa yang terjadi secara riil di lapangan serta kausalitasnya tidak mengenal ceteris paribus.

Faktor "negara lemah" (weak state) merupakan pra-kondisi penting, terutama menyangkut ketegasan dan kelugasannya menindak kelompok dan gerakan radikalfundamentalis agama. Baik aparatus kultural negara (misal: Departemen Pendidikan-Kebudayaan) maupun aparatus koersif negara (misal: Kepolisian) di Indonesia seperti kehilangan visi dan kelugasan. Kuat dan me-njamurnya sel-sel kelompok radikal-fundamentalis yang telah menyusup jauh ke berbagai instansi serta lembaga (baik pemerintah maupun swasta) merupakan faktor yang memungkinkan menjamurnya gejala yang ditandai paham radikal-fundamenetalis agama: dari sekolah, perguruan tinggi, bank, perusahaan, instansi-departemen pemerintah, sampai media. Di sini juga sentral peran partai-partai politik dan organisasi masa (ormas) yang kian telanjang meneriakkan ideologi dan agenda politik radikal-fundamentalis agama.

Demokrasi di Indonesia pada tahun 1998 adalah salah satu peristiwa yang menyebabkan sebuah gejolak yang tidak terbendungkan. Organisasi-organisasi agama, etnis, dan politik yang dulunya 'terkubur' karena rezim otoriter masa Orde Baru, kemudian bermunculan pada saat yang bersamaan dan menjamur di Indonesia. Transformasi drastis ini akhirnya menyebabkan euforia yang berlebihan dan cenderung negatif seperti anarkisme. Indonesia pun mendadak kehilangan kewibawaannya dan hampir mencapai sebuah keadaan yang sangat kacau (messy state) ${ }^{29}$

Hal yang sama terjadi dengan partai-partai politik. Dengan kedemokrasian yang sedang maraknya terjadi, semua penjabat pemerintahan, dari presiden hingga bupati, dipilih secara langsung oleh rakyat. Pilkada telah menjadi sebuah peristiwa dengan anggaran yang tidak terkirakan dan tujuan ideal partai politik, yaitu untuk mengontesasikan ideolosi, kini berubah menjadi sebuah tempat berburu kekuasaan. $^{27}$

Keadaan ini tentunya menimbulkan penolakan besar-besaran dari masyarakat dengan lahirnya gerakan-gerakan radikal dari masyarakat. Salah satu contoh kejadian adalah islamisasi besar-besaran pada masa itu. Terjadi perombakan konsep Islam dari tradisi Ahli Sunnah

\footnotetext{
${ }^{29}$ http://www.fsh.unsiq.ac.id/wpcontent/uploads/2 017/10/PDF-3.pdf.diunduh pada 21 April 2018.
} 
Wal-Jama'ah menjadi tradisi Ihwanul Muslimin. Munculnya partai-partai Islam yang baru pun disertai dengan runtuhnya partai-partai Islam yang menganut tradisi lama. $^{27}$

\section{Penyalahgunaan agama oleh oknum tidak bertanggung jawab}

Agama memberikan harapan bagi orang-orang yang dalam keadaan terpuruk dan dalam waktu-waktu yang diwarnai penderitaan. Agama sendirilah yang memberikan kita penjelasanpenjelasan akan tragedi, cara dunia bekerja, dan cara seseorang berperilaku. Bahkan, beberapa kode hukum dan kaidah nilai-nilai berdasar dari teks-teks agama. Agama pun merupakan satusatunya cara untuk merasionalisasikan ketidakberuntungan dan keberuntungan. Manusia tumbuh dan berkembang di dalamnya. Sebagai dampaknya, agama pun memiliki tempat yang khusus dalam hati kita. Hal ini sebenarnya bukan sesuatu yang buruk. Namun, ada kalanya beberapa figur dalam masyarakat menyalahgunakan relasi yang intim antara agama dan pola pikir kita tersebut. Mereka pun memprogasikan fanatisme terhadap agama dan "pemaknaan yang salah" mengenai teks-teks agama, kerapkali sebagai taktik politis. Dampaknya, hal ini pun melahirkan figur-figur agama yang radikal dan menyebarluaskan paham radikalisme agama. ${ }^{30}$

\footnotetext{
${ }^{30} \mathrm{http}: / / \mathrm{www}$. teenink.org/nonfiction/academic/arti cle/297208/Religious-Radicalism/ diunduh pada 21 April 2018.
}

\section{Kurangnya kesadaran hidup sesuai dengan Pancasila}

Faktor kurangnya kesadaran hidup sesuai dengan Pancasila. Setiap butir dari nilai Pancasila melambangkan cita-cita pendiri negara kita yang sejati yakni meliputi toleransi antar umat manusia, kebersamaan, dan kepedulian. Pancasila pada hakekatnya menyuarakan persatuan Indonesia dan kedamaian dan merupakan "mata rantai" yang menyatukan seluruh rakyat Indonesia dalam nilai-nilainya. ${ }^{31}$

Dengan nilai-nilai ketuhanan yang masa esa, kebersamaan, kepedulian, serta persatuan Indonesia yang tercantum dalam Pancasila, seharusnya bibit-bibit radikalisme akan dapat ditumpas dengan habis. Walaupun demikian, di zaman sekarang ini nilai-nilai Pancasila kurang diketahui, diamalkan, bahkan dimaknai oleh masyarakat Indonesia. Hal inilah yang merupakan faktor penyebab tumbuhnya radikalisme di Indonesia.

\section{Faktor Sosial}

Orang-orang yang mempunyai pikiran keras di mana di situ terdapat suatu kelompok garis keras yang bersatu mendirikan Tanzim al-Qaidah Aceh. Dalam keseharian hidup yang kita jalani terdapat pranata sosial yang membentuk pribadi kita menjadi sama. Situasi ini sangat menentukan kepribadian seseorang dalam melakukan setiap kegiatan yang dilakukan. Sistem sosial yang dibentuk oleh kelompok radikal atau garis keras membuat semua orang yang mempunyai tujuan sama dengannya bisa mudah berkomunikasi dan bergabung

31 Syam N., Tantangan multikulturalisme Indonesia: dari radikalisme menuju kebangsaan (Bekasi:Kanisius, 2009), 15. 
dalam garis keras atau radikal.

\section{Faktor Ideologi}

Faktor ini yang menjadikan seseorang yakin dengan apa yang diperbuatnya. Perbuatan yang mereka lakukan berdasarkan dengan apa yang sudah disepakati dari awal dalam perjanjiannya. Dalam setiap kelompok mempunyai misi dan visi masing-masing yang tidak terlepas dengan ideologinya. Dalam hal ini terorisme yang ada di Indonesia dengan keyakinannya yang berdasarkan Jihad yang mereka miliki.

\section{Faktor Psikologis}

Radikalisme dapat terjadi karena faktor psikologis, yaitu persepsi dan keyakinan orang mengenai kebenaran dan paham yang dianutnya yang diiringi dengan rasa kebutuhan untuk menghilangkan sudut pandang lain. ${ }^{32}$ Selain juga faktor pengalaman seseorang yang mengalami kepahitan dalam hidupnya, seperti kegagalan dalam karier, permasalahan keluarga, tekanan batin, kebencian dan dendam. Hal-hal tersebut dapat mendorong seseorang untuk berbuat penyimpangan dan anarkis. Abdurrahman al-Mathrudi menulis, bahwa sebagian besar orang yang bergabung kepada kelompok garis keras adalah mereka yang secara pribadi mengalami kegagalan dalam hidup dan pendidikannya. saudara muslim yang seperti itulah yang menjadi target sasaran orang radikal untuk diajak bergabung dengan mereka. Karena dalam keadaan seperti itu mereka sangat rentan dan

32 Hood, Hill, Spilka B., The psychology of religion: an empirical approach. Edisi keempat (New York: The Guilford Press, 2009), 2. mudah terpengaruh. ${ }^{33}$

Radikalisme dapat muncul salah satunya karena perasaan diperlakukan secara salah. Perasaan ini dapat berubah menjadi kebencian dan membuahkan tindakan radikal dengan dukungan lanjutan dari justifikasi berdasarkan poin tertentu dari Kitab Suci serta interpretasi yang salah terhadap poin tersebut.

\section{Faktor Pendidikan}

Pendidikan bukanlah faktor yang langsung menyebabkan radikalisme. Radikalisme dapat terjadi dikarenakan melalui pendidikan yang salah. Terutama adalah pendidikan agama yang sangat sensitif, kerena pendidikan agama "amal ma'ruf nahi munkar", namun dengan pendidikan yang salah akan berubah menjadi "amal munkar". Dan tidak sedikit orangorang yang terlibat dalam aksi terorisme justru dari kalangan yang berlatar pendidikan umum, seperti dokter, insinyur, ahli teknik, ahli sains, namun hanya mempelajari agama sedikit dari luar sekolah, yang kebenaran pemahamnya belum tentu dapat di-pertanggungjawabkan. Atau dididik oleh kelompok Islam yang keras dan memiliki pemahaman agama yang serabutan. ${ }^{34}$

Alwi Shihab mengutip pandangan Jean- Paul Satre ${ }^{35}$ bahwa selain faktor yang dipaparkan diatas, radikalisme agama juga terjadi karena orang-orang yang memegang teguh ajaran agama, untuk mencapai tujuannya, mereka menganggap tindakan radikal dalam agama suatu kebaikan. Justru karena adanya

\footnotetext{
${ }^{33}$ https://id:Wikipedia.org/wiki/Anarkisme\#Anark isme.dan.kekerasan diunduh pada 21 April 2018.

34 Olaf Herbert Schuman, Agama-Agama Kekerasan dan perdamaian (Jakarta: BPK: Gunung Mulia, 2015), 536.

${ }^{35}$ Alwi Shihab, Islam Inklusif (Bandung: Mizan, 1999), 146.
} 
asumsi bahwa penggunaan kekerasan merupakan salah satu metode pencapaian tujuan luhur, tidak aneh jika naluri agresif manusia kadang-kadang tumbuh subur di bawah naungan agama.

\section{Perkembangan Radikalisme- fundamentalisme Agama}

Radikalisme bukanlah hal yang asing bagi masyarakat, baik di kalangan nasional maupun internasional. Radikalisme dapat terjadi karena banyak faktor seperti yang sudah diuraikan di atas dan yang paling umum ialah mengenai persoalan ideologi agama. Seseorang yang menganut paham radikalisme akan menganggap bahwa orang lain dengan agama yang berbeda dari dirinya atau orang lain dengan pendapat yang berbeda walau agama yang sama sebagai musuh dan harus dimusnahkan. Tindakan radikalisme sudah terjadi sejak abad 7-8 masehi. Pada zaman itu, faktor penyebab peristiwa radikalisme adalah konflik internal di negara masing-masing dan perebutan kekuasaan antarnegara di dunia. ${ }^{36}$ Sumber utama perseteruan pasca perang dingin adalah identitas agama dan budaya yang disebut sebagai "benturan peradaban". Kekuatan ekonomi, militer, dan politik dari peradaban Barat selanjutnya dialihkan dengan munculnya "peradaban tandingan" lain, yaitu Islam (Muslim) dan Konfusius (Sino). ${ }^{37}$ Hal tersebut menjadi akar berkembangnya radikalisme ke segala kalangan di dunia.

\footnotetext{
${ }^{36}$ https://nasional.sindonews.com/read/1107997/1 4/sejarah-munculnya-radikalisme-1463048982 diunduh pada 21 April 2016.

37 Umar ARM. Melacak akar radikalisme di Indonesia (Jakarta: Sosial dan Ilmu Politik, 2010), 186.
}

Fenomena fundamentalisme merupakan keagamaan merupakan salah satu fenomena yang sangat memengaruhi dinamika dunia secara umum. Fenomena ini semakin kental belakangan ini terlihat melalui beragam tindakan kelompok intoleran terhadap kelompok atau komunitas keagamaan yang berbeda atau yang berseberangan dengan mereka. Tindakan kelompok intoleran ini pun kerap menyebabkan lahirnya gesekan dan konflik dalam masyarakat.

Walau kini dalam setiap agama dapat ditemukan pandangan yang bersifat fundamentalistis namun sebutan fundamentalis pada awalnya adalah sebutan yang diarahkan kepada sekelompok orang dalam komunitas Kristen yang menunjuk pada peristiwa kebangkitan kembali kekristenan pada awal abad ke-20 di Amerika Serikat. ${ }^{38}$ Hukum Curtis Lee pada tahun 1920 di Amerika menjadi momentum yang pertama diperkenalkannya istilah fundamentalisme. ${ }^{39}$ Hukum Curtis Lee ini dikeluarkan pada saat pertemuan Konvensi Baptis Utara. Curtis Lee Lewis menyebutkan bahwa "fundamentalis" sebagai seorang Kristen yang berjuang untuk mendapatkan kembali wilayah yang telah direbut anti Kristus dan "melakukan pertempuran kerajaan demi dasar-dasar iman". 40 Hukum itu dikeluarkan di tengah tekanan kekuasaan yang dialami oleh kelompok Protestan. Tradisi dan religiusitas yang terpelihara selama beberapa generasi kini diperhadapkan dengan tantangan dari evolusi dan berbagai kritik tingkat tinggi. Teori evolusi Darwin (1809-1882)

\footnotetext{
38 Richard M. Daulay, Religion in Politics (Jakarta: Libri, 2015) hal. 30

${ }^{39}$ Niels C. Nielsen, Jr, Fundamentalism, Mythos and World Religions (New York: State University of New York, 1993), 2.

40 Karen Armstrong, Masa Depan Tuhan (Bandung: Mizan, 2009), 437.
} 
mengejutkan tradisi keimanan Amerika dimana teori ini menyatakan menolak keyakinan bahwa dunia ini diciptakan dalam waktu enam hari sebagaimana yang dinyatakan dalam Kitab Kejadian, teori evolusi berkeyakinan bahwa semesta alam termasuk manusia mengalami evolusi. ${ }^{41}$

Kehadiran orang-orang nonProtestan seperti Katolik, Yahudi sebagai imigran Eropa karena industrialisasi juga membawa pengaruh besar dalam melahirkan semangat sekularisasi di Amerika. Modernisasi yang ditandai dengan industrialisasi dan sekularisasi menyebabkan diterimanya world view (gambaran dunia) yang baru, yang berdasarkan pada ilmu pengetahuan dan alam (sains) sebagai satu-satunya world view yang sah dan objektif. Penerimaan ini membuat terjadinya perubahan dan setiap elemen masyarakat di Amerika pun diharuskan untuk memberikan respon terhadap perubahan yang terjadi, tidak terkecuali dengan agama Kristen. Penerimaan ini menyebabkan penggambaran dunia dari kitab suci yang tadinya menjadi gambaran dunia berubah. Penggambaran itu kini dianggap sebagai peninggalan zaman yang sudah lewat atau tetap dipergunakan namun bermakna sebagai bahasa keagamaan, yang berbeda dengan bahasa ilmu pengetahuan. ${ }^{42}$

Penyesuaian ini tidak dapat diterima oleh semua kalangan Protestan, mereka menganggap bahwa penyesuaian ini membuat kekristenan tidak lagi murni. Kekristenan tidak boleh menyesuaikan diri dengan zaman, namun sebaliknya zaman dan dunialah yang harus dikristenkan. Keadaan ini membuat kalangan

\footnotetext{
${ }^{41}$ Richard M. Daulay, Op.Cit., 40

${ }^{42}$ Emmanuel Gerrit Singgih dalam Eko Prasetyo, dkk, Memahami Wajah Para Pembela Tuhan (Yogyakarta: Dian Interfidei, 2005), 90.
}

Protestan menyadari bahwa hanya dua pilihan yang diperhadapkan kepada mereka yaitu antara menerima atau menolak, menerima modernisasi sebagai liberalis atau bertahan dalam nilai dan mereka harus memberikan pilihan antara menerima dan bertahan, menerima modernisasi atau bertahan dalam nilai dan sikap yang lama sebagai fundamentalis. Dengan demikian dapat dikatakan bahwa fundamentalis seperti sebuah kelompok atau golongan yang menolak untuk terjadinya suatu asimilasi dari halhal yang baru dan membangun tembok pertahanan mereka sendiri.

Modernisasi di berbagai bidang juga terjadi di Eropa membuat tokohtokoh intelektual Eropa memprediksi bahwa modernisasi ini dapat mengesampingkan keberadaan agama sebagai elemen terpenting dalam kehidupan manusia. Sains dielu-elukan, rasionalisme dan pragmatisme dengan mengeliminasikan segala bentuk irasionalitas, tahayul, mitos-mitos dan berbagai ritual keagamaan. ${ }^{43}$ Secara positif keadaan ini melahirkan masyarakat yang lebih terbuka, rasional, toleran, pragmatis, humanistik sekaligus sekular. Keadaan ini tidak dapat diterima oleh semua pihak. Kalangan konservatif mengkhawatirkan keadaan tersebut akan membuat hilangnya keyakinan-keyakinan keimanan serta merosotnya wibawa dan pengaruh berbagai institusi keagamaan. Selain itu mereka juga mengkhawatirkan akan adanya penegasian peran agama sebagai petunjuk moral bagi perilaku individu maupun kolektif. Kelompok ini mengkhawatirkan jika keadaan ini akan menyebabkan anarki, dekadensi moral, dan kehidupan yang tidak beradab.

\footnotetext{
43 Samuel P. Huntington, Benturan Antar Peradaban (Jakarta: Qalam, 2012), 148.
} 
Pertengahan abad ke-20, terjadi perubahan situasi yang sangat berbeda dengan kondisi sebelumnya. Di tengah modernisasi yang tetap berlangsung, terjadi perubahan pendekatan keagamaan dan hal itu ditandai dengan bangkitnya semangat agama global. Gilles Keppel sebagaimana yang dikutip Samuel Huntington mengatakan pada setelah awal abad ke-20, terjadilah la revanche de Dieu (pembalasan Tuhan), di seluruh benua, di seluruh peradaban dan di berbagai negara. Kebangkitan keagamaan ini terjadi dalam setiap agama dan mendorong setiap orang untuk memberi makna serta semangat baru terhadap agama dalam komunitas agamanya masing masing. Semangat baru ini melahirkan gerakan-gerakan yang bersifat fundamentalistik dan militan. Semangat baru ini pula membangkitkan usaha yang bersifat puritanis (penyucian kembali) berbagai doktrin, institusiinstitusi keagamaan. Semangat puritanis ini jugalah yang mendorong mereka melakukan beragam usaha untuk membentuk perilaku personal maupun sosial yang terikat dengan ajaran-ajaran keagamaan. Gerakan yang bersifat fundamentalis ini sangat berseberangan dengan semangat pembaharuan yang didengungkan pembaharu sebelumnya. Bahkan gerakan ini berusaha dengan keras untuk mensakralkan tatanan sosial dan bila perlu mengubah masyarakat yang bersangkutan. Namun sangat disayangkan usaha pensakralan tatanan sosial itu dilakukan dengan cara-cara yang dipaksakan sehingga menghasilkan tindakan kekerasan, radikalis dan teror yang dilakukan oleh kelompok teroris yang gerakannya mengatasnamakan keagamaan tertentu untuk memberikan rasa takut terhadap banyak pihak.
Konflik yang bersumber dari kebangkitan sentimen keagamaan dan etnisitas telah diramalkan oleh beragam ahli dalam kumpulan tulisan yang dikumpulkan oleh Martin E. Marty dalam judul buku yang berjudul Nation in Turmoil, Etnicity and Self Identifity. Dalam buku itu dikatakan di abad ini ideologi komunisme, sosialisme, kapitalisme atau nasionalisme di masa lalu tidak lagi menjadi hal yang terlalu penting diperbincangkan di permukaan. Marty mengatakan gerakan keagamaan dan sentimen etnis yang militan akan menjadi perbincangan di dunia dan media massa karena kedua hal inilah yang kerap menjadi sumber konflik dan kekerasan. Agama (teks-teks keagamaan) akan menjadi pokok pembicaraan karena agama digunakan sebagai pembenaran dalam setiap konflik etnik dan kriminalitas kemanusiaan. Para pemeluk agama kerap bertikai dengan pemeluk agama lain yang menurut klaim masingmasing, demi mempertahankan "agama Tuhan". Agama pun berubah menjadi kekuatan pembunuh yang mengerikan, korup dan jahat.

Sumanto mengutip pandangan Charles Kimball yakni When Religion Becomes Evil, di mana ada beberapa tanda yang membuat agama menjadi busuk dan menimbulkan bencana, yaitu pertama: bila agama mengklaim kebenaran ajarannya, kitab sucinya, doktrinnya sebagai kebenaran mutlak dan satusatunya; kedua, ketaatan buta kepada pemimpin agama; ketiga, kerinduan agama terhadap adanya zaman ideal (negara teokratis atau negara agama); keempat, apabila agama tersebut membiarkan dan membenarkan tujuan yang menghalalkan segala cara; kelima, ketika pemeluknya memekikkan perang suci. ${ }^{44}$

\footnotetext{
${ }^{44}$ Sumanto Al Qurtuby, Op.Cit., 30.
} 
Wajah kekristenan sebagai agama yang berkekuatan pembunuh dan jahat melalui pekikan perang suci, sebagaimana yang dinyatakan oleh Charles Kimball, pertama kali disuarakan oleh Paus Urbanus II ketika mendeklarasikan Perang Salib. Pekikan "Deus vult" (Allah menginginkan), yang disuarakan orang Kristen menjadi respons sekaligus persetujuan banyak orang Kristen atas imbauan yang disampaikan oleh Paus Urbanus II dalam Konsili Clermont pada 27 November $1095 .^{45}$ Perang ini sendiri tidak lepas dari kejatuhan Kerajaan Bizantium Timur (Konstantinopel) ke tangan tentara Islam yang menyulitkan orang-orang Kristen Timur melakukan ziarah di daerah Bizantium Timur. Pengampunan dosa mereka dan saudara mereka serta janji kehidupan yang abadi melalui kasih Allah, yang diserukan Paus Urbanus kepada orang Kristen ketika itu menjadi pendorong utama lahirnya pekikan Deus Vult. Selain pekikan Deus Vult, janji yang diserukan oleh Paus Urbanus itu pulalah yang memantik semangat orang Kristen untuk terlibat dalam Perang Salib. ${ }^{46}$ Puncak ideologi perang suci atau perang salib ini dapat ditemukan dalam tulisan Moralitas Alkitab Codex 2554, yang dihasilkan antara tahun 1215 dan 1230, yang awalnya ditujukan pada anggota Keluarga Kerajaan Perancis. ${ }^{47}$ Codex ini sendiri ditulis ketika Perancis tengah menghadapi kelompok Albigensian (lebih sering disebut kelompok Kataris), yang ketika itu dianggap sebagai bidah atau sesat. Perang Salib yang sangat panjang

\footnotetext{
${ }^{45}$ Leo D. Lefebure, Penyataan Allah, Agama \& Kekerasan (Jakarta: BPK Gunung Mulia, 2006), 196.

46 Geth Allison \& Reid Powell, Orientation Amidst The Diversity, Holy War in The Bible, (USA: Inter Varsity Press, 2013), 27.

${ }^{47}$ Geth Allison, Op.Cit., 23
}

ini masih meninggalkan bekas luka yang sangat mendalam bagi orang Yahudi, orang Kristen mau pun orang Islam hingga saat ini.

Pekikan perang suci juga dilakukan oleh umat Islam dengan menyuarakan seruan untuk melakukan jihad. Seruan ini semakin sering diperdengarkan dewasa ini. Tidak jarang pekikan ini dimaknai sebagai suatu tugas suci di mana setiap umat diharuskan bergabung dengan militer melawan kelompok yang dianggap kafir, sebagaimana yang dilakukan oleh kelompok radikal. Pemahaman ini berbeda dengan pemahaman Islam mula-mula yang lebih memaknai jihad sebagai suatu usaha yang bersifat spiritualistis dan tidak bermakna militeristik meski tindakan militeristik diijinkan untuk mempertahankan kemerdekaan atau mempertahankan diri bukan untuk melakukan penyerangan. ${ }^{48}$ Makna jihad yang paling mendalam adalah menggumuli dan "membela diri" dari hal-hal yang merusak manusia dan hubungan dengan Tuhan seperti hawa nafsu yang menggoda manusia dan mengundang kelaliman atau secara prinsip membela diri dari hal-hal yang menjauhkan manusia dari Tuhan. Pergeseran makna ini pun pada akhirnya kerap mendorong tindak intoleran dan kekerasan atas nama agama.

Suara-suara kelompok fundamentalis keagamaan sempat meredup meski tidak sepenuhnya menghilang di tengah kebangkitan rasionalisasi, sekularisasi dan kemajuan zaman. Namun suara-suara fundamentalis keagamaan kembali muncul ke permukaan setelah naiknya Ayatollah Khoimeni di Iran menjatuhkan Syah Muhammad Pahlevi di Iran (1919-1980). Gagalnya penanaman semangat nasionalisme di beberapa

\footnotetext{
${ }^{48}$ Ibid, 48.
} 
negara di belahan dunia juga turut mempengaruhi kebangkitan fundamentalisme keagamaan. Misalnya kegagalan penanaman nasionalisme di Mesir pada masa pemerintahanan Anwar Al-Sadat (1918-1981). Di tengah penanaman nasionalisme justru pemuda Mesir menyuarakan seruan untuk mengenakan busana muslim dan pengambilalihan kampus-kampus dan mengklaimnya sebagai usaha kembali demi agama. Di Israel, lahirlah bentuk agama Zionisme yang agresif (yang semula sekuler) setelah kemenangan partai ultima Ortodoks yang dengan yakin diramalkan David Ben Gurion. ${ }^{49}$ Selain itu kegagalan berakarnya ideologiideologi seperti Marxisme atau Leninisme di berbagai belahan dunia juga turut memberi andil terhadap bangkitnya fundamentalis keagamaan. Itu sebabnya klaim yang bernada keagamaan dipakai untuk memperkuat identitas kebangsaan suatu negara. Misalnya Rusia yang mengambil nilai keagamaan dengan menjadikan Gereja Orthodox, sebagai Ibu Kudus Rusia. Jepang menegaskan agama Shintois untuk menjadi dasar yang mengikat kejiwaan bangsa Jepang, di Timur Tengah, Islam menjadi tenaga yang menguatkan umat Islam dan Timur Tengah dalam melakukan perlawanan terhadap militer Amerika Serikat. ${ }^{50}$

Identitas keagamaan inilah yang kemudian melahirkan politik identitas politik yang sering dipolitisasi. Misalnya kekerasan di Srilanka oleh kalangan fundamentalisme Budha, kekerasan di Iran atau Aljazair oleh fundamentalisme Islam, ${ }^{51}$ kekerasan di India oleh

\footnotetext{
${ }^{49}$ Karen Armstrong, Op.Cit., 466.

${ }^{50}$ Graham Fuller, A World Without Islam (New York: Back Bay Books, 2010), 307-308.

${ }^{51}$ Yaya Suryana \& H. A. Rusdiana, Pendidikan Multikultural (Bandung: Pustaka Setia, 2015), 174.
}

kelompok fundamentalis Hindu di India, 52 kekerasan antara Kristen Protestan dan Katolik di Irlandia, fundamentalisme Yahudi di Palestina oleh gerakan Block of Faithful yang dipimpin oleh Gush Emunim. Perbincangan mengenai fundamentalisme keagamaan memang tidak pernah hilang sama sekali dalam kehidupan manusia namun perbincangan mengenai radikalisme fundamentalisme keagamaan kembali menjadi topik pembicaraan penting setelah peristiwa kehancuran menara WTC pada 11 September 2001.

Seorang sejarawan Islam dan orientalis terkemuka, mengatakan bahwa radikalisme dalam bidang keagamaan mulai berkembang pesat setelah peristiwa kejadian 11 September 2001. Pada hari itu, di Amerika Serikat, terjadi empat serangan terorisme yang pada akhirnya membunuh 2,966 orang dan menyebabkan luka-luka pada lebih dari 6,000 orang lainnya. Serangan terorisme tersebut dilakukan oleh kelompok teroris Islam bernama Al-Qaeda. Kejadian ini diawali dengan pembajakan empat pesawat komersil, dua pesawat di antaranya menabrak kedua gedung World Trade Center di New York, satu pesawat menabrak gedung Pentagon di Virginia, dan satu pesawat jatuh di Pennsylvania. Pendapat Lewis disampaikan dalam konteks kaitan antara gerakan keagamaan yang mengandung aksi bom bunuh diri dengan wacana keagamaan yang bersifat fundamental. Fundamentalisme dianggap sebagai sikap anti-barat yang diperlihatkan melalui tindakan radikalisme yang bersifat ekstrem, seperti aksi bom bunuh diri, Lewis berpendapat bahwa doktrin jihad ini merupakan pembenaran dalam pelaksanaan perang yang bersifat suci

\footnotetext{
${ }^{52}$ Niels C. Nielsen, Jr, Op.Cit., 103-118.

${ }^{53}$ Ibid, 71.
} 
dengan tujuan teror yang bersifat tidak suci (holy war and unholy terror). Kesimpulan yang dapat diambil menurut Lewis adalah adanya keterkaitan antara konsep tentang fundamentalisme, terorisme, kebangkitan gerakan keagamaan, dan tindakan jihad. 54 Yudha mengutip pandangan John L. Esposito mengenai kebangkitan gerakan keagamaan, khususnya Islam, di kalangan dunia pasca perang dingin dan peristiwa 11 September 2001. Esposito melakukan suatu analisis dalam bukunya The Islamic Threat: Myth or Reality (1992). Analisis tersebut ditujukan kepada kebangkitan gerakan Islam pasca perang dingin, berpendapat bahwa kebangkutan tersebut merupakan respon dari ideologi modernisasi dan westernisasi yang berselisih dengan nilai-nilai yang dianut oleh agama Islam. ${ }^{55}$

\section{Radikalisme Agama di Indonesia}

Paham radikalisme muncul di Negara Indonesia sejak masa pemerintahan Orde Lama dan mengalami perkembangan yang signifikan setelah masa pemerintaahan Orde Baru, terutama dengan terbentuknya banyak kelompok gerakan Islam dan Islam politik. Ada dua hal yang dapat menyebabkan pembentukan kelompok gerakan keagamaan Islam di Indonesia. Pertama, relasi yang fluktuatif antara Negara Indonesia dengan umat Islam pasca peristiwa kemerdekaan. Kedua, adanya penindasan ekonomipolitik kepada kelompok Islam. Dominasi yang dilakukan oleh pihak negara yang bersifat oligarkis ini membuat para

\footnotetext{
54 http://lib.ui.ac.id/file?file=digital/20302292T30635\%20-\%20Radikalisme\%20kelompok.pdf diunduh pada 21 April 2018.

${ }^{55}$ Ibid.
}

penganut paham radikalisme mulai bermunculan untuk melakukan perlawanan. ${ }^{56}$

Di masa pemerintahan Orde Lama, salah satu kelompok gerakan Islam yang menganut paham radikalisme adalah Darul Islam/Tentara Islam Indonesia atau DI/TII. Pemimpin DI/TII adalah Sekarmadji Maridjan Kartosoewiryo dan beliau membentuk kelompok ini dengan tujuan mendirikan Negara Islam Indonesia (NII). Atau yang lebih dikenal dengan Darul Islam. Perlawanan kepada pemerintahan Indonesia pun dianggap sebagai bentuk jihad. 57 Paham radikalisme ini pertama kali dicetuskan di Tasikmalaya, Jawa Barat pada tahun 1949. Tujuan diberdirikannya gerakan ini adalah untuk menjadikan Indonesia menjadi sebuah negara Islam terutama pada awal kemerdekaan Indonesia dimana konsep pemerintahan Indonesia saat itu belum terlalu sempurna dan masih mudah digoyahkan. Pemberontakan ini pun kemudian menjalar ke berbagai belahan Indonesia seperti di Sulawesi Selatan, Kalimantan Selatan dan juga Aceh. Kemudian, pada tahun 1962, terjadi pemberantasaan DI/TII.

Setelah itu pada masa pemerintahan Orde Baru, terbentuk kembali kelompok gerakan Islam radikal lain yang disebut sebagai kelompok ekstrem kanan. Kelompok-kelompok ini dituduh telah melakukan gerakan subversif atau gerakan yang ingin menjatuhkan kekuasaan negara. Beberapa di antaranya adalah Komando Jihad dan Jamaah Islamiah (JI). Contoh kejadian radikalisme pada masa pemerintahan Orde Baru adalah peledakan Candi Borobudur pada tanggal 21 Januri 1985. Kejadian ini pun

\footnotetext{
${ }^{56}$ Ibid

${ }^{57} \mathrm{http}$ ///simbi.kemenag.go.id/pustaka/images/mate ribuku.pdf diunduh pada 21 April 2018
} 


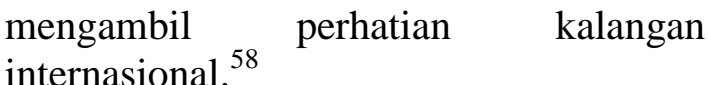

Radikalisme mulai merambah di masyarakat luas sejak zaman lengsernya pemerintahan Presiden Soeharto dimana akhirnya masyarakat mendapatkan hak mereka untuk berpendapat secara bebas. Kebebasan untuk mengemukakan ide inilah yang menjadi pemicu awal timbulnya paham-paham yang sifatnya non-Pancasila dan bersifat mengancam kedaulatan NKRI. Munculnya ideologi yang menyimpang ini juga salah satunya disebabkan oleh belum terlaksananya Ideologi Pancasila secara menyeluruh mengingat umur Indonesai yang membuat pemaparan Ideologi Pancasila ini kurang sempurna dan menimbulkan kecemburuan antar masyarakat sehingga orang-orang tersebut lebih memilih untuk menciptakan sebuah paham yang menurut mereka lebih adil dan realistis bagi mereka. ${ }^{59}$

Sikap radikalisme juga masih sering dijumpai dan jumlahnya bertambah banyak. Umumnya pergerakan radikalisme pada era ini mengacu kepada penolakan sistem pemerintahan Indonesia yang menganut sistem politik demokrasi. Pada saat ini, kebanyakan pergerakan radikalisme merambat melalui organisasi kemasyarakatan dengan media sosial sebagai perantara pengajaran paham radikalisme. Tidak jarang pergerakan kaum radikal ini menggunakan kekerasan dalam pemberontakannya seperti kelompok radikal FPI.

Berbagai perseteruan komunal yang didasarkan dengan hal keagamaan muncul setelah masa pemerintahan Orde Baru berakhir, seperti di Poso dan

\footnotetext{
${ }^{58}$ Ibid.

${ }^{59}$ http://www.nu.or.id/post/read/78246/radikalism e-agama-di-indonesia diunduh pada 21 April 2018.
}

Ambon. Perseteruan tersebut memicu pembentukan beberapa kelompok gerakan Islam radikal lainnya, seperti MMI (Majelis Mujahidin Indonesia), FPI (Front Pembela Islam), dan Laskar Jihad. Ketiga kelompok ini diduga mempunyai keterlibatan langsung dalam perseteruan di Poso maupun di Ambon berupa pengiriman para-militer atau laskar. ${ }^{60}$ Rakhmatulloh mengutip pandangan Mubarak mengenai riset radikalisme yang memaparkan bahwa faktor yang menyebabkan perkembangan pemahaman radikalisme dan ekstremisme yang dianut kelompok gerakan Islam adalah ketidakefektifan kinerja pemerintahan dalam menanggapi isu-isu sensitif, terutama isu yang berhubungan dengan umat Islam sehingga gerakan radikalisme dibentuk sebagai upaya penggulingan kekuasaan politik oleh pemerintahan Indonesia. ${ }^{61}$ Faktor lainnya adalah faktor eksternal dan internal dari negara. Faktor eksternal berupa perkembangan situaasi ekonomi, politik, sosial, dan budaya, sedangkan faktor internal berupa doktrin dalam hal keagamaan di dalam kelompok gerakan Islam itu sendiri. Kedua faktor ini semakin menguatkan dan menyebarkan ideologi radikalisme di kelompok gerakan Islam di Indonesia. ${ }^{62}$

Kelompok gerakan Islam terbentuk karena kelompok-kelompok ini ingin memerjuangkan nilai-nilai yang dianutnya. Radikalisme dalam konteks ini adalah bentuk perlawanan terhadap ideologi yang dianut negara dan dunia yang berbeda dari nilai-nilai dalam Agama Islam dan juga bentuk arus balik marjinalisasi Agama Islam di masa pemerintahan Orde Baru. ${ }^{63}$ Kelompok

\footnotetext{
${ }^{60}$ Ibid.

${ }^{61}$ Ibid

${ }^{62}$ Ibid.

${ }^{63}$ Umar ARM. Op.Cit., 169-186.
} 
fundamentalis keagamaan melakukan beragam aksi dan tindakan yang menarik perhatian beragam media untuk meliput dan memberitakannya secara luas termasuk di Indonesia. Perubahan peta politik di Indonesia pasca Reformasi 1998 menjadi momentum yang paling mempengaruhi kehadiran kelompok fundamentalis keagamaan. Beragam aturan seperti pencabutan UU Anti Subversi dan kebebasan pers memberikan angin segar kepada kelompok fundamentalisme keagamaan untuk menyebarkan paham yang mereka anut. Selain itu kemerosotan kekuasaan pemerintah pusat, penerapan otonomi dan desentralisasi melahirkan beragam perda yang berbau keagamaan di berbagai daerah di Indonesia. Misalnya Perda No. 6/2002 di daerah Solok mewajibkan memakai busana Muslim, Perda No. 3 Tahun 2001 tentang desa Pekraman dan di Manokwari, Papua Barat yang mengklaim dirinya sebagai Kota Injil. ${ }^{64}$ Beragam perda ini tentu saja menimbulkan berbagai implikasi dan konsekuensi yang tidak diharapkan dalam kehidupan masyarakat di sekitarnya. Keadaan politik Indonesia khususnya penghapusan UU Anti Subversi dan semakin melemahnya kekuasaan pusat membuat kelompok keagamaan garis keras di Indonesia dapat bertumbuh dengan pesat. Pertumbuhan ini pulalah yang kemudian membangkitkan kembali keinginan mereka yang sempat dipadamkan pemerintah Orde Baru yaitu menjadikan Indonesia sebagai negara Islam (dakwah Islamiyah) dan kekhalifahan (khilafah). ${ }^{65}$

64 Bidang Marturia PGI, Diskursus Hubungan Agama dan Negara,(Jakarta: BPK Gunung Mulia, 2014), 63.

${ }^{65}$ Olaf Schumman, Agama-agama Kekerasan dan Perdamaian, (Jakarta: BPK Gunung Mulia, 2015), ix.
Keadaan Indonesia yang ditinjau melalui berbagai faktor menjadi salah satu alasan mengapa pergerakan radikalisme masih senantiasa ada di Indoneisa. Salah satu faktor yang mendukung timbulnya radikalisme di Indonensia adalah kurangnya pemahaman ajaran agama atau iman yang kuat sehingga lebih mudah untuk mengalami penyimpangan ajaran agama. Selain itu, ketidakadilan dan kesenjangan sosial juga menjadi salah satu faktor pendukung tingginya angka radikalisme di Indonesia. Perkembangan teknologi dan kemudahan akses internet juga turut mendukung tumbuhnya kaum radikal di tanah air. Kemudahan akses media cetak, elektronik, sosial membuat mudahnya transfer informasi. Kemudahan itu diiringi dengan semakin banyaknya media komunikasi yang memuat berita atau artikel yang sedikit berhubungan dan berkolerasi dengan unsur radikalisme. Radikalisme tidak hanya menyangkut sebuah kegiatan atau aksi yang besar, melainkan bermula dari tindakantindakan kecil yang berkembang dengan pesat. ${ }^{66}$ Pemerintah memperketat pengawasan terhadap organisasi masyarakat yang berbasis agama dan membubarkan kelompok radikal yang bertentangan dengan Pancasila. Selain itu, pemerintah Indonesia juga membubarkan salah satu kelompok radikal yang anti-Pancasila, yaitu Hizbut Tahrir Indoensia (HTI).

\section{Pengaruh Radikalisme dan Ancaman bagi Generasi Muda}

Generasi merupakan sebutan bagi orang-orang yang lahir pada kisaran tahun yang sama sehingga memiliki

\footnotetext{
${ }^{66}$ https://nasional.tempo.comuda/read/87453/medi a diunduh pada 21 April 2018.
} 
hubungan sosial dan sosio-sejarah yang mirip dan membentuk karakter yang mirip. ${ }^{67}$ Generasi muda yang dimaksud adalah kelompok kaum muda atau pemuda, remaja dan anak. Masa muda pada umumnya dipandang sebagai suatu tahap dalam pembentukan kepribadian manusia dalam proses mencari jati diri. Pemuda adalah individu yang secara fisik sedang mengalami pertumbuhan jasmani dan secara psikis sedang mengalami perkembangan emosional. Dengan begitu pemuda merupakan sumber daya manusia pembangunan baik saat ini maupun masa mendatang. ${ }^{68}$

Generasi muda memiliki posisi yang penting dan strategis karena menjadi poros bagi punah atau tidaknya sebuah negara, Benjamine Fine dalam bukunya 1.000.000 Deliquents, mengatakan "a generation who will one day become our national leader". Generasi muda adalah pelurus dan pewaris bangsa dan negara ini, baik buruknya bangsa ke depan tergantung kepada bagaimana generasi mudanya, apakah generasi mudanya memiliki kepribadian yang kokoh, memiliki semangat nasionalisme dan karakter yang kuat untuk membangun bangsa dan negaranya (nation and character), apakah generasi mudanya memilki dan menguasai pengetahuan dan teknologi untuk bersaing dengan bangsa lain dalam tataran global dan tergantung pula kepada apakah generasi mudanya berfikir positif untuk berkreasi yang akan melahirkan karyakarya nyata yang monumental dan membawa pengaruh dan perubahan yang besar bagi kemajuan bangsa dan negaranya.

\footnotetext{
${ }^{67}$ Ibid.

68 https://www. kompasiana. com/teruntukgenerasi-muda-bangsa diunduh pada 22 April 2018.
}

Data Badan Nasional Penanggulangan Terorisme (BNPT) pada Forum Bela Negara Alumni UI (BARA UI) bahwa pelaku teroris terbesar berpendidikan SMA yakni 63,3 persen, perguruan tinggi 16,4 persen, SMP 10,9 persen, tidak lulus perguruan tinggi 5,5 persen, dan SD 3,6 persen. Berdasarkan umur, pelaku teroris terbanyak usia 21-30 tahun yakni 47,3 persen, disusul usia 31 40 tahun 29,1 persen. Sedangkan, usia di atas 40 tahun dan di bawah 21 tahun masing-masing 11,8 persen. Mengacu pada data tersebut maka pelaku teroris didominasi oleh generasi muda dengan tingkat pendidikan SMA/sederajat. ${ }^{69}$ Menurut data BNPT bahwa pada tahun 2018 ini dimana hampir setengah Generasi Muda Indonesia terkena paham radikal. $^{70}$

Pengaruh radikalisme terhadap generasi muda banyak terjadi dengan perkembangan teknologi yang bebas dan mudah diakses, serta berbagai faktor lain yang dapat menyebabkan generasi muda tersebut dapat terpengaruh. Menurut LIPI faktor penyebab generasi muda terpengaruh bersikap radikal dan intoleran, antara lain faktor pendidikan yang rendah. Di Indonesia 1,05 persen pemuda berumur enam belas hingga tiga puluh tahun belum mendapatkan akses pendidikan formal dan bahkan 0,64 persen tidak bisa membaca dan menulis, dengan kata lain buta huruf. ${ }^{41}$ Tetapi hal ini tidak menutup kemungkinan juga pada seseorang dengan latar pendidikan tinggi juga dapat berpotensi radikal. Faktor kelurga juga dapat berperan dalam proses

\footnotetext{
69 http://indonews.id/artikel/10083/Radikalismepada-Generasi-Muda-Perlu-Penanganan-Serius/, diunduh 22 mei 2018.

${ }^{70}$ https://www.suara.com/news/2018/04/25/16022 9/hampir-setengah-generasi-muda-indonesiaterkena-paham-radikal, diunduh pada 22 April 2018
} 
ini. $^{71}$

Krisis identitas juga dapat menjadi sebab. Secara umum, target perekrutan anggota kelompok radikal ataupun ekstrimisme berasal dari kelompok generasi muda yang masih dalam tahap pencarian jati diri. Sangat mudah dalam proses perekrutan generasi muda seperti ini, dengan dengan mempengaruhi pola pikir dan perilaku target, baik dengan cara dialog, ceramah atau ritual.

Pengaruh radikalisme terhadap generasi muda dapat menjadikan mereka sebagai kaum yang radikal dengan sifat destruktif dan keras. Ketika mereka menemukan orang yang tidak sepaham timbullah keributan dan kerusuhan sampai pada tindakan menghilangkan nyawa orang lain dengan berbagai cara. Pemikiran kaum muda menjadi rusak, dari pemikiran yang sehat kemudian menjadi agen radikalisme yang berbahaya bagi bangsa.

Melihat banyaknya dampak negatif yang ditimbulkan, maka Kementerian Komunikasi dan Informasi RI memberikan beberapa langkah yang dapat dilakukan dalam menghadapi masalah ini terutama generasi muda. Pertama, harus berhati-hati dengan judul berita yang bersifat provokatif. Kedua, diimbau memperhatikan alamat situs. Ketiga, harus memeriksa fakta serta foto yang diberikan dalam suatu informasi, apakah fakta dan foto tersebut benar. Terakhir, pemerintah telah membuat UndangUndang tentang ITE yang mengatur tentang media sosial. ${ }^{72}$

Edukasi dan bimbingan tetap diberikan kepada generasi muda dengan

71

http://www.bbc.com/indonesia/beritaindonesia/2016/02/160218-indonesia-radikalismeanak-muda, diunduh pada 22 Mei 2018

${ }^{72}$ http://sinta.ukdw.ac.id/sinta/resources/sintasrv/n im/01021871 diunduh pada 22 April 2018. memperhatikan bahwa yang sedang dibimbing adalah seorang makhluk berakal budi yang sedang bertumbuh dan berubah dalam pemikirannya sehingga refleksi dan evaluasi diri mengenai nilainilai, ekspektasi, dan standar yang dimiliki generasi muda perlu dihargai dan dipertimbangkan dalam pengajaran sehingga ada keterbukaan mengenai etis, moral, harapan, serta mimpi dari generasi untuk menjadi generasi yang berakhlak moral dan berbudi pekerti luhur berdasarkan nilai-nilai ideologi Pancasila dan sebagai generasi muda Kristen dengan nilai-nilai kekristenan.

\section{Pandangan Alkitab Terhadap Radikalisme Fundamentalisme}

Radikalisme fundamentalisme dalam Kitab Suci merupakan bagian yang tidak terpisahkan dalam kehidupan umat beragama tanpa terkecuali. Kitab suci secara keseluruhan, bukan hanya isi atau maknanya, tetapi juga sebagai kitab (secara material) sering masih dianggap sungguh-sungguh suci, mengandung kekuatan ilahi dan bisa mendatangkan berkat atau kutuk. ${ }^{73}$ Secara positif kitab suci merupakan sumber ajaran moral, aturan hukum yang mengarahkan kehidupan, inspirasi, spiritualitas, pemberi semangat kepada umat beragama untuk hidup yang lebih baik lagi. Secara negatif kitab suci juga kerap dijadikan sumber pembenaran suatu tindak intoleran atau kekerasan atas nama agama. Kitab suci dianggap sebagai legitimasi teologis dan dasar ideologis kelompok fundamentalis radikalis dalam membenarkan tindak kekerasan atas nama agama.

\footnotetext{
${ }^{73}$ A. Sudiaraja, Agama di Zaman yang Berubah (Yogyakarta: Kanisius, 2006), 95.
} 
Dalam kehidupan gereja terutama umat Protestan mewarisi pandangan Marthin Luther yang terkenal dengan slogannya sola scriptura, hanya oleh kitab suci. Slogan sola scriptura merupakan slogan yang dilahirkan Marthin Luther untuk mengembalikan otoritas kitab suci dalam kehidupan gereja yang menurut Luther telah dirampas oleh otoritas tradisi gereja. Ditempatkannya kitab suci sebagai sentral kehidupan gereja membuat kitab suci menjadi acuan pokok bagi gereja untuk merumuskan suatu pandangan, pemikiran teologi, pola pikir atau cara pandang umat Kristen dalam memandang keberadaan mereka yang beragama lain. Untuk itu diperlukan suatu penafsiran Alkitab yang bertanggung jawab oleh gereja agar pesan teks yang tepat dapat disampaikan kepada warga jemaat.

Gereja harus menafsirkan Alkitab secara bertanggung jawab dan menjadi tugas khusus, khususnya rohaniwan Kristen terlebih terhadap berbagai teksteks Alkitab yang kerap disalahpahami oleh jemaat yakni teks-teks yang menampilkan kesan kaku dan tertutup serta eksklusif dalam memahami dan bersikap umat beragama lain. Pemahaman kitab suci yang kurang tepat dapat menyebabkan terjadinya distorsi epistemology ${ }^{74}$ dalam memandang absolutisme keagamaan, yang semula diharapkan hanya untuk memperkokoh komitmen ilahiah pemeluk agama secara terhadap agama yang dianutnya namun ternyata justru berkembang ke arah ekstremisme mentah (juvenile extremism), yang menumbuh-

\footnotetext{
74 Distorsi epistemologi adalah penyimpangan pemahaman, pemaknaan atau pengetahuan. Distorsi epistemology dalam memaknai teks kitab suci yang awalnya hanya bersifat eksklusif pada dasarnya bersifat personal, pribadi bergeser menjadi tolok ukur dalam memandang keberadaan agama lain
}

suburkan sikap eksklusif.

Alkitab juga mencatat berbagai teks-teks yang dapat menumbuhsuburkan sikap eksklusif di antaranya mengenai umat yang terpilih (Ulangan 7:6 band. Rom. 11:17), Yesus sebagai satu-satunya jalan kebenaran dan hidup (Yoh. 14:6), dan keyakinan bahwa tidak ada keselamatan lain selain dalam nama Tuhan Yesus Kristus (Kis. 4:12). Teksteks seperti inilah yang kemudian melahirkan ungkapan populer dalam kehidupan orang Kristen, "No Other Name", yang meyakini bahwa tidak ada nama lain selain Yesus Kristus. Keyakinan ini kemudian membuat orang Kristen membentuk Laskar Yesus dalam rangka melawan orang Islam atau siapa saja yang dipandang mengganggu kesucian teks tersebut. ${ }^{75}$ Gereja khususnya gereja di Indonesia perlu melakukan rekonstruksi dalam memahami pesan dan makna dari teks-teks ini. Rekonstruksi harus dilakukan gereja karena gereja hidup di tengah masyarakat Indonesia yang majemuk secara keagamaan. Gereja perlu memperbaiki cara pandang dan cara memahami kitab suci secara berbeda dari yang selama ini diwariskan para missionaris.

Rekonstruksi terhadap Alkitab merupakan keharusan bagi gereja khususnya gereja Protestan karena keberadaan Alkitab yang begitu sentral dalam kehidupan gereja khususnya sebagai sumber ajaran atau pun doktrin kristen. Selain rekonstruksi terhadap teks-teks yang bersifat eksklusivisme, gereja juga perlu menggali lebih dalam lagi teks-teks Alkitab yang kerap dianggap sebagai dasar atau pembenaran pemahaman fundamentalis melakukan tindak

\footnotetext{
${ }^{75}$ Sumanto Al Qurtuby, Jihad Melawan Ekstremis Agama (Semarang: Borobudur Indonesia Publishing, 2009), 58.
} 
intoleran atau kekerasan atas nama agama. Misalnya kisah pembunuhan Habel oleh Kain (Kej. 4:1-6) kerap dijadikan pembenaran bahwa agama adalah sumber kekerasan.

Menurut Olaf Schuman bahwa kekerasan dan agama adalah dua hal yang saling bertentangan satu dengan yang lain. Kisah pembunuhan Habel oleh Kain (Kej. 4:1-6), menurut Schuman tidak dapat dijadikan sebagai acuan untuk membenarkan pendapat bahwa agama adalah sumber dari kekerasan atau pembunuhan. ${ }^{76}$ Anggapan bahwa agama sebagai sumber kekerasan menurut Schuman tidak terlepas dari sudut pandang Kain yang menganggap bahwa Allah membenci Kain dan karena itulah Allah menolak persembahan yang diberikannya. Sudut pandang Kain mengenai Allah ternyata tidak benar, Allah tidak pernah membenci Kain sebaliknya Kain tetap berada dalam perlindungan Allah (ay. 15). Kesalahan Kain dalam memahami agama menjadi salah satu alasan yang membuat agama dianggap menjadi sumber kekerasan. Berdasarkan hal itulah Olaf Schuman menolak anggapan bahwa agama dijadikan sebagai sumber tindak kekerasan karena menurut Schuman, agama dan kekerasan itu sesungguhnya adalah dua hal yang bertentangan.

Ada pandangan yang berbeda dari Schuman yakni Liere van Lucien. Teologi menurut Lucien, menemukan dua sisi yang paradoks atau bertentangan dalam memahami agama dan kekerasan. Lucien melihat ada dualism yang saling bertentangan terhadap Allah, sebagai pusat dari agama: Allah menolak kekerasan, Allah yang penuh cinta, dan

${ }^{76}$ Olaf Schuman, Agama-agama Kekerasan \& Perdamaian (Jakarta: BPK Gunung Mulia, 2015), 489-491. lain-lain. Namun di sisi lain Allah dalam kitab suci khususnya Alkitab ditemukan Allah sebagai subjek (pelaku) kekerasan. Secara sepintas Allah tidak hanya menolak kekerasan begitu saja tapi Allah juga menjadi pelaku kekerasan: Allah membunuh, Allah memerintahkan untuk membunuh, memerintahkan melakukan genosida, membenci, dan lain-lain. Selain memberikan perintah-perintah itu, Allah juga dinilai memiliki emosi-emosi yang negatif seperti marah, kecewa, iri, dan lain-lain. ${ }^{77}$ Pertentangan inilah yang kemudian membuat Lucien menyatakan agama memiliki andil bagi terjadinya tindak intoleran dan kekerasan.

Dalam kitab Ulangan 13:6-9, menuliskan "apabila saudaramu laki-laki, anak ibumu, atau anakmu laki-laki atau anakmu perempuan atau isterimu sendiri atau sahabat karibmu membujuk engkau diam-diam, katanya : Mari kita berbakti kepada allah lain yang tidak dikenal olehmu atau pun nenek moyangmu, salah satu allah bangsa-bangsa sekelilingmu, baik yang dekat kepadamu maupun yang jauh dari padamu, dari ujung bumi ke ujung bumi, maka janganlah engkau mengalah kepadanya dan janganlah mendengarkan dia. Janganlah engkau merasa sayang kepadanya, janganlah mengasihani dia, dan janganlah menutupi salahnya, tetapi bunuhlah dia! Pertamatama dengan tanganmu sendirilah yang bergerak membunuh dia, kemudian seluruh rakyat". Selain ada ayat lain yang dapat menjadi inspirator bagi pelaku kekerasan, yaitu ayat "siapa yang mengutuk kamu (Israel) maka terkutuklah dia dan siapa yang memberkatimu maka berkatilah dia" (Kej. 27:9). Tokoh Gereja Konservatif Amerika Jarry Falwell ber-

\footnotetext{
77 Lucien van Liere, Memutuskan Rantai Kekerasan (Jakarta: BPK Gunung Mulia, 2010), 72.
} 
kampanye kepada jemaat Kristen guna menggalang solidaritas Yahudi dan mengecam Palestina. ${ }^{78}$

Dalam Alkitab Perjanjian Baru juga terdapat teks yang dapat dimaknai sebagai pendorong tindak kekerasan. Tulisan PB melalui perkataan Yesus, sosok yang dikenal mengajarkan kasih, damai ternyata juga pernah memberikan pernyataan yang mengejutkan di mana Yesus mengatakan :"Janganlah kalian pikir bahwa Aku datang ke dunia ini untuk membawa damai. Aku datang bukan untuk membawa damai, tetapi membawa pedang, yaitu pertentangan yang hebat" (band. Mat. 10:34). Teks ini haruslah diinterpretasi dengan cara baru, sehingga tidak akan mengarahkan pada pandangan radikalisme fundamentalisme yang berbahaya.

Lukas 6:27-36 tertulis "Tetapi kepada kamu, yang mendengarkan Aku, Aku berkata: Kasihilah musuhmu, berbuatlah baik kepada orang yang membenci kamu; Barangsiapa menampar pipimu yang satu, berikanlah juga kepadanya pipimu yang lain, dan barangsiapa yang mengambil jubahmu, biarkan juga ia mengambil bajumu. Berilah kepada setiap orang yang meminta kepadamu; dan janganlah meminta kembali kepada orang yang mengambil kepunyaanmu. Dan sebagaimana kamu kehendaki supaya orang perbuat kepadamu, perbuatlah juga demikian kepada mereka. Dan jikalau kamu mengasihi orang yang mengasihi kamu, apakah jasamu? Karena orangorang berdosapun mengasihi juga orangorang yang mengasihi mereka. Sebab jikalau kamu berbuat baik kepada orang yang berbuat baik kepada kamu, apakah jasamu? Orang-orang berdosapun berbuat demikian. Dan jikalau kamu me-

\footnotetext{
${ }^{78}$ Sumanto, Op.Cit., 57
}

minjamkan sesuatu kepada orang, karena kamu berharap akan menerima sesuatu dari padanya, apakah jasamu? Orangorang berdosapun meminjamkan kepada orang-orang berdosa, supaya mereka menerima kembali sama banyak. Tetapi kamu, kasihilah musuhmu dan berbuatlah baik kepada mereka dan pinjamkan dengan tidak mengharapkan balasan, maka upahmu akan besar dan kamu akan menjadi anak-anak Allah Yang Mahatinggi, sebab Ia baik terhadap orangorang yang tidak tahu berterima kasih dan terhadap orang-orang jahat. Hendaklah kamu murah hati, sama seperti Bapamu adalah murah hati.mintalah berkat bagi orang yang mengutuk kamu; berdoalah bagi orang yang mencaci kamu." Sebagai murid Yesus dituntut untuk menjadi radikal. Sampai sekarang Umat Kristen dituntut untuk mengasihi secara radikal, yakni untuk perdamaian dan kasih. Matius 22:37-39 "Kasihilah Tuhan, Allahmu, dengan segenap hatimu dan dengan segenap jiwamu dan dengan segenap akal budimu. Itulah hukum yang terutama dan yang pertama. Dan hukum yang kedua, yang sama dengan itu, ialah: Kasihilah sesamamu manusia seperti dirimu sendiri. Pada kedua hukum inilah tergantung seluruh hukum Taurat dan kitab para nabi." Dengan demikian dapat disimpulkan bahwa keradikalan Yesus adalah mengasihi Allah dan sesama manusia. Yang dimaksud dengan sesama adalah semua orang, tidak memandang kawan atau lawan. Musuh sekalipun harus dikasihi. 


\section{Peran Gereja dalam PAK dalam Menghadapi Bahaya Radikalisme Fundamentalime yang Mengancam Generasi Muda}

Radikalisme fundamentalisme yang diwarnai dengan kekerasan, yakni: teror, bom, pembunuhan, dan seterusnya adalah sesuatu yang mengancam stabilitas bangsa dan negara dan juga merusak perdamaian sesama ciptaan Tuhan. Hal ini sangat bertentangan dengan Damai Sejahtera Kristus. Menurut Djoys dalam buku Resolusi Konflik dalam organisasi menuliskan bahwa damai adalah ketenangan batin, rasa tenteram dan sejahtera. Damai adalah harmoni dan kerja sama. Damai adalah kenyataan ketika semua orang mengalami keadilan dan kewajaran dalam masyarakat. Damai adalah situasi di tengah masyarakat ketika konflik diselesaikan dengan tanpa kekerasan. $^{79}$

Tindakan-tindakan radikalisme yang menghancurkan dan membinasakan manusia dan ciptaan Tuhan lainnya adalah sesuatu yang berbahaya dan sangat diwaspadai. Gereja harus berperan penting dalam pengajaran, pembinaan dalam pokok-pokok pengajaran terutama dalam Pendidikan Agama Kristen kepada segala usia terutama kepada anak-anak muda sebagai generasi muda. Sebab generasi muda adalah generasi penerus bangsa dan gereja. Memperhatikan segala bentuk bahaya, ancaman dan faktorfaktor yang mempengaruhi seseorang bisa terpengaruh dengan berbagai ajaran atau doktrin yang mengarah pada kesesatan apalagi doktrin radikalisme

\footnotetext{
${ }^{79}$ Djoys Anneke Rantung, Resolusi Konflik dalam Organisasi-Kajian dari Perspektif Pendidikan Perdamaian terhadap Kasus Konflik di Lembaga Pendidikan (Jakarta: BPK Gunung Mulia, 2017), 47.
}

fundamentalisme garis keras, yakni dengan cara berjihad atau berperang apalagi bom bunuh diri.

Sikap gereja terhadap masalah ini seharusnya sama dengan apa yang Yesus ajarkan dalam Alkitab: radikalisme ialah suatu virus yang harus dilawan, namun bukan dengan pembalasan dan kekerasan. Peran gereja dalam menghadapi radikalisme sangatlah dibutuhkan dalam masyarakat, mengingat bahwa masalah ini merupakan masalah yang harus diselesaikan bersama-sama oleh semua lapisan masyarakat, termasuk gereja.

Di Indonesia sendiri, peran gereja dalam menghadapi radikalisme dapat dilihat dari berbagai tindakan dan langkah yang telah diambil oleh Persekutuan Gereja-Gereja di Indonesia. Pada tanggal 11-12 September 2015, PGI menyelenggarakan kegiatan Dialog Gereja, Masyarakat, dan Agama-agama di Palangkaraya. Sidang tersebut membahas tantangan utama yang dihadapi gereja, dimana radikalisme menjadi salah satu di antara 4 masalah utama yang dibahas, yakni: Kemiskinan, Keadilan, Lingkungan Hidup dan Radikalisme. Hasil dari sidang tersebut selanjutnya disosialisasikan kepada gereja-gereja, tujuannya agar gerakan tersebut tidak hanya tertutup pada para pemimpin gereja, tetapi juga melibatkan gerakan dari selurut umat Kristen. PGI mendorong gereja-gereja untuk bersikap toleran terhadap sesama serta berkomitmen untuk menentang bentukbentuk penindasan terhadap kemanusiaan. Dengan demikian, sikap dan tindakan yang dilakukan gereja dapat dikatakan selaras dengan firman Tuhan dalam Alkitab.

Sama halnya dengan peran pemerintah, gereja juga mengambil peran yang penting untuk menghadapi bahaya radikalisme fundamentalisme agama. 
Peran penting yang dilakukan oleh gereja berdasarkan perintah Tuhan, yakni kasih, keadilan, kebaikan, damai sejahtera (band. Matius 22:39). Peran Gereja tidak terlepas dari peran pemerintah dalam melawan radikalisasi. Gereja sebagai bagian dari negara terpanggil untuk terlibat dalam mendukung pemerintah. Gereja sebagai salah satu pelaku PAK berkewajiban untuk menolong pemerintah menyukseskan program softderadikalisasi. Penegakan Hukum di Indonesia memiliki dasar, yaitu Pasal 29 Undang-Undang Dasar 1945. Negara ini telah menjamin hak pribadi setiap warganya untuk beragama dan beribadah menurut keyakinannya. Karena itu radikalisme atas nama agama di Indonesia harus dihadapi dengan sikap yang tegas yaitu dengan penerapan hukum. Tidak boleh menghadapi radikalisme ini dengan kekerasan tanpa hukum, atau bertoleransi apalagi membiarkan radikalisme itu berkembang di Indonesia.

Penerapan hukum yang tegas, juga dapat menjamin hidupnya demokratisasi di Indonesia, seperti persamaan hak (equality), kebebasan (liberty), dan persaudaraan (fraternity). Penerapan hukum yang radikal seperti ini, akan menjamin, menghargai, melindungi dan memfasilitasi hak-hak setiap warga Negara Republik Indonesia. Penerapan hukum itu dibutuhkan karena hanya dengan cara itu, keutuhan negara akan dapat dipertahankan. Penerapan hukum itu dibutuhkan karena hanya dengan cara itu, negara dapat dihindarkan dari kekacauan dan kemungkinan untuk runtuhnya sebuah negara.

Penerapan hukum secara tegas dibutuhkan sebab, hingga kini, radikalisme yang berkembang di Indonesia jelas memiliki tujuan tertentu. Karena itu menghadapi sikap radikalisme adalah dengan softderadikalisme, dengan empat
(4) pilar kebangsaan Indonesia yaitu (1), Pancasila sebagai Karakter Bangsa Indonesia, (2) UUD '45, (3). NKRI, sebagai Rumah Bersama untuk semua anak bangsa, dan (4). Bhineka Tunggal Ika sebagai semboyan Bersatu dalam Kepelbagaian. Pemerintah yang tegas dalam menghadapi radikalisme dengan hukum akan membuat negara makin kuat, sebaliknya penerapan hukum yang lemah akan makin menumbuhkan radikalisme yang menghancurkan bukan saja demokratisasi di Indonesia, menghancurkan Negara Kesatuan Republik Indonesia.

Kerjasama gereja dan pemerintah dalam program-program bersama sangatlah dibutuhkan. Beberapa hal yang perlu dilakukan dalam menghadapi bahaya radikalisme fundamentalisme, adalah:

Gereja bersama semua orang Kristen, tidak boleh berhenti untuk memperjuangkan dan membela keadillan, kasih dan kebenaran bagi siapapun. Bukan saja kepada saudaranya yang gerejanya ditutup oleh kelompokkelompok radikalisme. Gereja dan Orang Kristen harus berjuang atas nama keadilan untuk siapapun di Indonesia ini. ${ }^{80}$

Gereja harus menghancurkan sekatsekat pemisah di antara sesama gereja dan berusaha membangun jejaring baik di kalangan sesama Gereja atau sesama umat maupun dengan umat dari agama lainnya serta dengan semua kelompok dan masyarakat yang peduli dan memperjuangkan persamaan hak (equality), kebebasan (liberty), dan persaudaraan (fraternity). ${ }^{81}$

Gereja patut sungguh-sungguh dan tulus membangun kesadarannya dan umat Kristen bahwa keseriusan dengan iman

\footnotetext{
80 http://www.leimena.org/id/page/v/8/institutleimena diunduh pada 22 April 2018.

${ }^{81}$ Ibid.
} 
Kristen sama berartinya dengan menyadari dan menghargai pluralitas Negeri ini dan sama berharganya dengan upaya menegakkan keadilan, menyatakan kepeduliaan kepada orang miskin, dan sama berartinya dengan memperjuangan keadilan, kebenaran dan cinta kasih. ${ }^{82}$

Gereja adalah salah satu pelaku PAK yang sangat berperan untuk memberikan pengajaran dan pendidikan iman Kristen. Gereja sebagai pelaku PAK memainkan peranannya dengan melibatkan diri dalam usaha yang dapat membebaskan atau membantu jemaat menghadapi penyebaran ideologi fundamentalis. Untuk itu gereja perlu melakukan suatu pendidikan agama yang tidak menyudutkan keberadaan agama lain. Gereja perlu membuat kurikulum pendidikan agamanya yang membuka ruang bagi pengenalan dan perjumpaan dengan agama lain, yakni kurikulum intereligius.

Peran Gereja dalam PAK dapat diwujudkan dalam kurikulum-kurikulum dengan metode dan materi yang sangat berhubungan dengan pendidikan, pengajaran, pembinaan tentang karakter kristiani. PAK yang dilakukan gereja tidak cukup hanya berbicara tentang doktrin semata namun juga membicarakan tentang agama yang lain atau agama yang berbeda dan juga ajaran-ajarannya untuk lebih mengenal dan menghargai keberadaan umat beragama lain. ${ }^{83}$ Demikian juga dengan pendidikan agama Kristen, selama agama Kristen itu ada maka pendidikan agama Kristen tetap harus dilangsungkan. Melakukan pendidikan agama Kristen juga adalah

82 Weinata Sairin, Visi Gereja Memasuki Milenium Baru (Jakarta: BPK Gunung Mulia, 2002), 67-68).

${ }^{83}$ Mery Kolimon dalam Frans Magnis Suseno, Agama Keterbukaan dan Demokrasi (Yogyakarta : Paramadina, 2015), 37. perwujudan orang Kristen melakukan perintah Yesus sebelum Dia naik ke surga. Dia berkata "dan ajarlah mereka melakukan segala sesuatu yang telah Kuperintahkan kepadamu...." (band. Mat. 28:20) merupakan perintah yang jelas dan tegas yang diberikan Yesus kepada murid-murid-Nya sebelum naik ke surga.

Perintah untuk mengajarkan menjadi bagian dari amanat atau perintah Yesus yang sangat penting. Gereja perlu menginterpretasi pemahaman yang tepat mengenai Kitas Suci, terutama Alkitab. Karena gereja merupakan pihak yang paling bertanggungjawab dalam pelaksanaan PAK meski memang ruang lingkup PAK tidak hanya terjadi dalam komunitas gereja. PAK dapat dilakukan di dalam keluarga atau pun lingkungan sekolah namun PAK merupakan tugas utama gereja. Gereja melakukan PAK bukan hanya untuk mewariskan kekayaan iman Kristen, tradisi atau ritual kekristenan kepada warga jemaat. Gereja tidak boleh lepas tangan dan membiarkan hanya orang tua atau pun sekolah yang melakukan PAK karena di gerejalah tersedia para pengajar yang telah dipercayakan untuk mengambil peranan sebagai rasul-rasul maupun nabi-nabi, pemberita-pemberita Injil, gembalagembala dan para pengajar-pengajar (Ef. 4:11). ${ }^{84}$ Tugas Gereja sangat penting bersama dengan keluarga dan sekolah.

Gereja memiliki panggilan untuk mencerminkan kasih Allah kepada dunia sekitarnya. Kasih ini didasari dengan sifat Allah sendiri yang adalah kasih, dinyatakan dalam 1 Yohanes 4:8 yang berbunyi, "Barangsiapa tidak mengasihi, ia tidak mengenal Allah, sebab Allah

\footnotetext{
${ }^{84}$ E. G. Homrihausen \& I. H. Enklaar, Dinamika Pendidikan Kristen, (Jakarta : BPK Gunung Mulia, 2013), 21.
} 
adalah kasih." Hal ini mengingatkan gereja untuk mengasihi semua orang tanpa melihat asal budaya atau agama mereka untuk mencegah bertumbuhnya radikalisme. Didasari pemahaman bahwa kabar baik berupa Injil bukan hanya untuk sebagian kaum saja, tetapi untuk semua bangsa. Pada Injil Lukas, disebutkan bahwa bangsa Yahudi harus mengasihi musuh, yang dimaksud musuh dalam kitab tersebut adalah orang dengan kepercayaan yang berbeda. Lukas 6:2736 mengingatkan untuk membalas kejahatan dengan kebaikan, terutama dalam ayat ke-29, "Barang siapa menampar pipimu yang satu, berikanlah juga kepadanya pipimu yang lain, dan barangsiapa yang mengambil jubahmu, biarkan juga ia mengambil bajumu." Tamparan pipi pada waktu itu merupakan salah satu tindakan yang paling merendahkan, namun harus tetap tidak dibalas kembali dengan tindakan kejahatan. Sebagai salah satu usaha untuk menghadapi ancaman radikalisme adalah untuk mendoakan kaum radikalis dan membalas setiap tindakan mereka yang berdasarkan kekerasan dengan kebaikan, disertai dengan pembawaan kabar baik demi keselamatan mereka. ${ }^{85}$

Pendidikan Agama Kristen memiliki peran yang sangat penting untuk menjadi dasar dari perilaku kaum intelektual sebagai generasi penerus bangsa. Pengajaran Kristiani didasari oleh kasih sebagaimana seharusnya dimiliki seorang murid Kristus, dikatakan di Yohanes 13:34-35, "Aku memberikan perintah baru kepada kamu, yaitu supaya kamu saling mengasihi; sama seperti Aku telah mengasihi kamu demikian pula kamu harus saling mengasihi. Dengan demikian semua orang akan tahu, bahwa

\footnotetext{
${ }^{85}$ https://www.gmim.or.id/mtpj diunduh pada 22 April 2018.
}

kamu adalah murid-murid-Ku, yaiu jikalau kamu saling mengasihi." Kasih yang dipraktikkan dalam keseharian sebagai umat percaya yang mendapatkan Pendidikan Agama Kristen, atau yang sebagaimana harusnya diajarkan di PAK berupa kasih yang membedakan orang percaya dari penganut paham lainnya, yaitu kasih yang tidak pandang bulu dan tidak memerlukan imbalan apapun meskipun objek kasihnya tidak layak dikasihi. ${ }^{86}$

Sebagai alat menghadapi radikalisme, PAK juga hendaknya menekankan sikap toleransi antarumat beragama demi menjaga integrasi yang terdapat di Indoensia. Umat Kristiani seharusnya mempraktikkan sikap toleran sebagai penghormatan dan penerimaan umat agama lain tetapi tetap berpegang kepada Kristus dan bukan menjadi sama dengan umat agama lain. Hal ini ditunjukkan di Ulangan 10:18-19 menuliskan," Sebab TUHAN, Allahmulah Allah segala allah dan Tuhan segala tuhan, Allah yang besar, kuat dan dahsyat, yang tidak memandang bulu ataupun menerima suap; yang membela hak anak yatim dan janda dan menunjukkan kasih-Nya kepada orang asing dengan memberikan kepadanya makanan dan pakaian. Sebab itu haruslah kamu menunjukkan kasihmu kepada orang asing, sebab kamu pun dahulu adalah orang asing di tanah Mesir."

Dalam Lukas 9:52-56 menuliskan mengenai misi penyebaran Injil Yesus dan murid-muridNya di Samaria. Mereka mengalami penolakan, namun muridNya berpikira bahwa Yesus ingin membinasakan orang yang menolak ajarannya. Yesus berpaling dari mereka dan menegor mereka karena ketidaksabaran dan

\footnotetext{
${ }^{86}$ Gill J. John, Exposition of the old and the new testaments (Arkansas: The Baptist Standard Bearer, 2006), 23.
} 
kekeliruan mereka yang menjadikan pemikiran mereka berlawanan dengan pengajaran kasih Kristus. Seharusnya tidak ada dendam yang dipendam untuk mereka yang belum percaya dan masih hidup dengan berbagai dosa. Pada akhir ayat tersebut pada translasi King James Version, "For the Son of man is not come to desroy men's lives, but to save them." Hal ini menyatakan bahwa kasih Allah ada untuk setiap umat dan karya keselamatannya tidak terbatas pada segelintir orang saja. ${ }^{87}$ Nainggolan mengutip pandangan Bushnell bahwa pendidikan agama Kristen diharapkan dapat memberikan pengalaman belajar secara teratur di sepanjang kehidupan orang Kristen. Hal itu dapat dilakukan melalui liturgi kebaktian, baik melalui khotbah, pembacaan dan penelaahan supaya setiap orang Kristen diperlengkapi untuk memanfaatkan iman Kristen yang semakin matang (Ef. 4:12-14) sehingga setiap orang Kristen mampu menyoroti beragam masalah kehidupan sedemikian rupa, menjadi warga negara yang setia kepada Tuhan dalam pelaksanaan tugas masing-masing. Pembelajaran PAK itulah yang digunakan oleh gereja untuk membimbing warga jemaatnya yang hidup di tengah kemajemukan dan keragaman keagamaan. Keberagaman dan kepelbagaian agama membuat setiap orang Kristen dipastikan senantiasa bersentuhan dengan penganut agama-agama lain. Pembelajaran PAK yang tepat akan menolong setiap orang-orang Kristen untuk lebih mudah mengaplikasikannya. PAK yang dilakukan gereja hendaklah mencakup empat prinsip utama yang harus dipenuhinya di tengah ke-

${ }^{87}$ Henry M. Matthew, Commentary on the Whole Bible: New Modern Edition (Massachusets: Hendrickson Publishers; 2009), 9. beragaman, yaitu : ${ }^{88}$

Learning to know : PAK diarahkan untuk peningkatan pengetahuan jemaat, pengetahuan akan Allah dan segala firmanNya, sesama, diri sendiri, maupun lingkungannya. Jemaat hendaklah diarahkan kepada pemahamahan akan keutuhan seluruh ciptaan sebagai suatu kesatuan yang saling ketergantungan dan harus dijaga agar tetap harmoni sesuai rencana Allah

Learning to do : PAK yang dilakukan gereja mengarahkan agar jemaat memiliki keterampilan dalam mempraktekkan imannya, bukan menjadi batu sandungan, bukan menutup diri namun untuk menghadirkan damai sejahtera di tengah dunia

Learning to be : PAK yang dilakukan gereja membantu warga jemaat menyatakan keberadaannya dalam kehidupannya sehari-hari untuk kepentingan sesama. Gereja menanamkan bahwa jemaat tidak hidup hanya untuk dirinya sendiri namun juga bagi sesama dan lingkungannya

Learning to live together : PAK yang dilakukan gereja harus memberikan kesadaran kepada jemaat untuk menerapkan kasih Kristus melampaui batas-batas keagamaan atau pun etnisitas.

Keempat prinsip utama dalam menjalankan PAK tersebut hanya akan tercapai bila gereja melakukan reformulasi pengajaran yang selama ini diwarisinya. Harus diakui bahwa gereja mewarisi cara pandang orang Kristen Barat dalam memandang keberadaan agama lain, PAK di Indonesia pun memiliki kecenderungan negatif terhadap keberadaan agama lain, di mana keberadaan agama orang-orang non Kristen

\footnotetext{
${ }^{88}$ Jhon M. Nainggolan, PAK dalam Masyarakat Majemuk (Bandung : Bina Media Informasi, 2009), 22-24
} 
adalah kafir yang tak bertuhan dan untuk Islam disebut sebagai orang-orang yang percaya pada satu Allah walau masih menyembah macam-macam allah dan orang suci lain, dan oleh karenanya mereka menjadi objek sasaran pekabaran Injil. $^{89}$

Di masa Penjajahan Jepang, gereja membuka mata untuk mengadakan perubahan yang kemudian mendorong dibukanya sekolah-sekolah teologi dan dihidupkannya teologi in loco. Hal ini diawali dengan kesadaran gereja-gereja di Indonesia akan pentingnya kemandirian dan melepaskan diri dari gereja-gereja induk di Barat. Sikap dan cara pandang negatif terhadap keberadaan mereka yang beragama lain harus dihilangkan karena sikap dan cara pandang itu dapat menjadi tembok pemisah yang menghambat hubungan dengan penganut agama lain serta dapat menjadi sumber terciptanya kebencian dan kekerasan atas nama agama.

Tugas PAK menjadi pekerjaan dua rangkap, yang pertama tentu saja yaitu memerlengkapi para peserta didik dalam tradisi iman mereka sendiri, dan yang berikutnya adalah memungkinkan mereka untuk selalu terbuka kepada pihak yang berasal dari tradisi agama lain. Groome menyebutkan perlunya untuk selalu mengingatkan praktisi PAK (guru agama, dosen, dan lainnya), bahwa mereka bukanlah pemilik perusahaan atau lembaga namun agama mereka adalah salah satu ekspresi darinya, dan bahwa mereka berbagi suatu pencarian ikatan bersama semua pendidik agama dari komunitas agama yang lain. ${ }^{90}$

\footnotetext{
${ }^{89}$ N. K. Atmadja Hadinoto, Dialog dan Edukasi (Jakarta : BPK Gunung Mulia, 1990), 180.

${ }^{90}$ Thomas H. Groome, Christian Religious Education, (Jakarta: BPK Gunung Mulia, 2011), 34.
}

PAK yang baik adalah membuat peserta didik terangsang untuk melihat kemungkinan-kemungkinan yang lebih luas, termasuk adanya kebenaran yang berbeda dari apa yang telah diyakininya. Penggunaan kekristenan sebagai alat mediasi Paulus terhadap tradisi keyahudian dalam masyarakat Helenistik adalah dasar yang membuat PAK harus mampu mendialogkan perbedaan yang ada dalam pengambilan kesimpulan. Hal ini menjadi wahana bagi peserta didik untuk dapat menjalin hubungan yang saling menghormati dengan orang-orang yang berbeda keyakinan atau identitas keagamaan. Pengajaran Agama sering memberikan penekanan tentang "kebenaran" yang bersifat mutlak, tertutup atau satu-satunya, sehingga menghasilkan sikap beragama yang tertutup dan eksklusif.

PAK yang kontekstual di Indonesia bersifat mendorong peserta didik untuk memberikan "pengaruh" yang bermanfaat bagi lingkungan mereka melalui "kekhasan" perkataan dan tingkah laku. Pola ini menjauhkan peserta didik dari sikap menghakimi atas perbedaan yang ada. PAK melatih anak-anak dalam pengakaran dasar kekristenan yang berbuah dalam pola hidup dan tingkah laku mereka. Pola hidup ini dipupuk bukan hanya untuk kebaikannya atau komunitas kekristenan semata, tetapi harus menjadi kesaksian kebaikan bagi "orang lain." Semangat yang seperti inilah yang harus selalu ditumbuh-kembangkan dalam metode, kurikulum, dan pengajaran PAK untuk Indonesia yang damai sejahtera.

Tugas-tugas gereja sebagai pelaku PAK dalam menghadapi bahaya radikalisme-fundamentalisme yang mengancam generasi muda, lewat pengajaran dan pembinaan secara praksis, yakni gereja harus mengajarkan kepada generasi muda bahwa radikalisme agama yang menciptakan konflik dan terorisme 
harus dilawan Radikalisme Cinta Kasih (band. Matius 22:37-40). Bersama-sama membangun umat beragama yang matang yang menghayati spiritualitas keugaharian dan mampu mengontrol diri dan berkontribusi untuk mengusahakan keadilan, kesetaraan dan kemanusiaan. Yesus adalah role model dalam radikalisme cinta: keadilan, kesetaraan dan kemanusiaan. Pengajaran Yesus itulah perbuatannya, sehingga seluruh kehidupan Yesus adalah pengajaran akan kehidupan. Intitusi pendidikan pada dasarnya merupakan tempat untuk memanusiakan manusia. Semua harus menanamkan nilai-nilai Pendidikan perdamaian. Gereja harus memberlakukan PAK yang kontekstual yang senantiasa sesuai dengan situasi dan konteks yang ada dan yang dibutuhkan. Tugas gereja sebagai pelaku PAK adalah memperlengkapi umat Kristen termasuk generasi muda dengan tradisi iman dan selalu terbuka dan menghargai keberadaan agama lain dan sesama ciptaan Tuhan.

Pendidikan Agama Kristen juga berguna untuk menanamkan nilai-nilai Pendidikan anti kekerasan dan terorisme sebab di Alkitab. Berikut beberapa nilai yang penting untuk diajarkan dalam Pendidikan Agama Kristen dalam menghadapi radikalisme-fundamentalisme : ${ }^{91}$

a. Citizenship, yaitu kualitas pribadi seseorang yang terkait hak-hak dan kewajibannya sebagai warga negara dan warga bangsa. Misalnya, hak dan kewajiban dalam memanfaatkan mengembangkan kemajuan IPTEK dengan prinsip untuk kebermanfaatan bangsa dan negara. Ini juga untuk menanamkan jiwa nasionalis supaya

\footnotetext{
${ }^{91}$ Muchlas Samani dan Hariyanto. Konsep dan Model Pendidikan Karakter ( Bandung : Rosoda, 2011), hal.54
}

mempertahankan persatuan dan kesatuan bangsa, yang secara tidak langsung berlawanan dengan paham radikalisme-fundamentalisme ini.

b. Compassion, yaitu kepedulian terhadap penderitaan atau kesedihan orang lain serta mampu menanggapi perasaan dan kebutuhan mereka.

c. Courtesy, yaitu berperilaku santun dan berbudi bahasa yang halus sebagai perwujudan rasa hormat kita terhadap orang lain.

d. Fairness, yaitu berlaku adil, bebas dari favoritism maupun fanatisme golongan, seperti Yesus yang tidak memandang bulu orang lain, Ia menyembuhkan perempuan Samaria yang pada saat itu berdosa.

e. Moderation, yaitu menjauhi pandangan dan tindakan yang radikal dan ekstrem yang tidak rasional atau tidak masuk akal. Ini sekaligus melawan paham radikalisme fundamentalisme terorisme.

f. Respect for other, yaitu menghargai hak-hak dan kewajiban orang lain, tidak merenggut HAM mereka.

g. Respect for the Creator, menghargai segala karunia yang diberikan oleh Tuhan Sang Maha Pencipta dan merasa berkewajiban untuk selalu menjalankan segala perintahNya dan menjauhi segala laranganNya serta senantiasa bersyukur atas anugrah yang datang daripadaNya.

h. Self control, yaitu mampu mengendalikan diri melalui keterlibatan emosi dan tindakan seseorang. Tidak main hakim sendiri.

i. Tolerance, yaitu dapat menerima penyimpangan dari hal yang dipercayai atau praktik-praktiik yang berbeda dengan yang dilakukan atau dapat menerima hal-hal yang bersebrangan dengan apa yang telah menjadi kepercayaan diri. 


\section{Penutup}

Pengaruh radikalisme terhadap generasi muda sekarang banyak terjadi dengan perkembangan teknologi yang bebas dan mudah diakses. Oleh karena itu, pengaruh radikalisme pada generasi muda saat ini pun dapat terlihat seperti perkembangan sifat destruktif dan keras. Ada banyak faktor yang mempengaruhi adanya radikalisme-fundamentalisme agama, seperti faktor rasa nasionalisme, agama, globalisasi, pemikiran, ekonomi (kemiskinan dan kesenjangan), kekuasaan politis dan lemahnya negara, penyalahgunaan agama oleh oknum yang tidak bertanggung jawab, kurangnya kesadaran hidup sesuai Pancasila, sosial, ideology, psikologis, pendidikan, dan lain sebagainya.

Radikalisme fundamentalisme agama yang bersifat negatif, pengaruhnya terhadap seluruh lapisan masyarakat juga kepada generasi muda, tentu memiliki dampak yang dihasilkan baik secara fisik maupun mentalitas, yaitu: 1). Kerusakan fisik, pemahaman radikalis biasanya tidak mentolerir adanya perbedaan yang berbeda dengan ajaran mereka. Hal ini biasanya didominasi oleh atas dasar agama. Beberapa dari mereka menganggap bahwa kekerasan terhadap mereka yang tidak sepaham dengan mereka merupakan suatu tindakan yang memuliakan allah mereka. Hal ini sangat krusial karena banyak nyawa tidak bersalah yang bisa menjadi korban atau bahkan melayang karena aksi mereka. Sebagai contoh, doktrin Jihad dan Istisyhad dalam ajaran agama Islam menjadi dasar yang seringkali disalahgunakan oleh para radikalis untuk melakukan aksi kekerasan. Tindakan kekerasan seperti penyerangan massa dan bom bunuh diri pun mengakibatkan banyak korban jiwa melayang dan kerusakan fisik seperti infrastruktur. 2). Kerusakan mentalitas, selain kekerasan yang mereka lakukan, salah satu bahaya yang menjadi poin penting adalah kerusakan mentalitas yang diakibatkan pada masyarakat dengan pendirian lemah. Paham radikalisme menjadi suatu racun bagi mereka yang belum menemukan jati diri mereka dengan baik, umumnya pada kalangan remaja dan anak-anak. Radikalisme yang negatif akan menurunkan semangat nasionalis yang tentu saja mengarah pada perpecahan dalam masyarakat. Radikalisme juga akan berdampak pada kesehatan rohani seseorang yang akhirnya tidak didasarkan pada kebaikan.

Peran Gereja tidak terlepas dari peran pemerintah dalam melawan radikalisasi. Gereja sebagai bagian dari negara terpanggil untuk terlibat dalam mendukung pemerintah. Gereja sebagai salah satu pelaku PAK berkewajiban untuk menolong pemerintah menyukseskan program softderadikalisasi. Penegakkan Hukum di Indonesia memiliki dasar, yaitu Pasal 29 Undang-Undang Dasar 1945. Negara ini telah menjamin hak pribadi setiap warganya untuk ber-agama dan beribadah menurut keyakinan-nya. Karena itu radikalisme atas nama agama di Indonesia harus dihadapi dengan sikap yang tegas yaitu dengan penerapan hukum. Tidak boleh meng-hadapi radikalisme ini dengan kekerasan tanpa hukum, atau bertoleransi apalagi membiarkan radikalisme itu berkembang di Indonesia.

Penerapan hukum yang tegas, juga dapat menjamin hidupnya demokratisasi di Indonesia, seperti persamaan hak (equality), kebebasan (liberty), dan persaudaraan (fraternity). Penerapan 
hukum yang radikal seperti ini, akan menjamin, menghargai, melindungi dan memfasilitasi hak-hak setiap warga Negara Republik Indonesia. Penerapan hukum itu dibutuhkan karena hanya dengan cara itu, keutuhan negara akan dapat dipertahankan. Penerapan hukum itu dibutuhkan karena hanya dengan cara itu, negara dapat dihindarkan dari kekacauan dan kemungkinan untuk runtuhnya sebuah negara.

Peran Gereja dalam PAK dapat diwujudkan dalam kurikulum-kurikulum dengan metode dan materi yang sangat berhubungan dengan pendidikan, pengajaran, pembinaan tentang iman Kristen. Pendidikan agama bukanlah pendidikan yang baru diperkenalkan pada masa modern, karena pendidikan agama itu seusia dengan kehadiran agama itu sendiri. Tiap-tiap agama mempunyai sistem, isi dan bentuk pendidikannya masing-masing. Ini berarti selama agama itu ada maka pendidikan agama itu juga tetap akan dilangsungkan. Gereja adalah salah satu pelaku PAK yang sangat berperan untuk memberikan pengajaran dan pendidikan iman Kristen. Gereja sebagai pelaku PAK memainkan peranannya dengan melibatkan diri dalam usaha yang dapat membebaskan atau membantu jemaat menghadapi penyebaran ideologi fundamentalis. Untuk itu gereja perlu melakukan suatu pendidikan agama yang tidak menyudutkan keberadaan agama lain. Gereja perlu membuat kurikulum pendidikan agamanya yang membuka ruang bagi pengenalan dan perjumpaan dengan agama lain.

\section{Daftar Pustaka}

Alkitab, Lembaga Alkitab Indonesia, 2011.

Alwi Shihab, Islam Inklusif, Bandung: Mizan, 1999.

Adnon Nasrullah Jamaludin, Agama dan Konflik Sosial-studi kerukunan umat beragama, Radikalisme dan Konflik antar umat beragama, Bandung: Pustaka Setia, 2015.

Armada Riyanto, Membongkar Eksklusivisme Beragama dalam AgamaKekerasan, Membongkar Eksklusivisme, Malang : Dioma, 2000.

Atmadja Hadinoto N.K., Dialog dan Edukasi, Jakarta: BPK Gunung Mulia, 1990.

Bidang Marturia PGI, Dirkursus Hubungan Agama dan Negara, Jakarta: BPK Gunung Mulia, 2014.

Djaka Soetapa, Seri Seminar Masa Depan Bangsa dan Radikalisme Agama Bandung: Gunung Djati Press, 2006

Djoys Anneke Rantung, Resolusi Konflik dalam Organisasi-Kajian dari Perspektif Pendidikan Perdamaian terhadap Kasus Konflik di Lembaga Pendidikan Jakarta: BPK Gunung Mulia, 2017.

Emmanuel Gerrit Singgih dalam Eko Prasetyo, dkk, Memahami Wajah Para Pembela Tuhan Yogyakarta: Dian Interfidei, 2005.

Endang Turmudzi dkk, Islam dan Radikalisme di Indonesia Jakarta: LIPI Pres, 2004

Ermaya Suradinata, Seri Seminar Masa Depan Bangsa dan Radikalisme Agama Bandung: Gunung Djati Press, 2006.

Gill J. John, Exposition of the old and the new testaments Arkansas: The Baptist Standard Bearer, 2006.

Graham Fuller, A World Without Islam 
New York : Back Bay Books, 2010.

Herry Priyono, Radikalisme-Fundamentalisme Agama dan Faktor Ekonomi Jogjakarta: Universitas Kristen Duta Wacana, 2017.

Henry M. Matthew, Commentary on the Whole Bible: New Modern Edition Massachusets:

Hendrickson Publishers, 2009.

Hoo, Hill PC, Spilka B. The psychology of religion: an empirical approach. Edisi keempat New York: The Guilford Press, 2009.

Homrihausen E.G. \& I. H. Enklaar, Dinamika Pendidikan Kristen, Jakarta: BPK Gunung Mulia, 2013.

Hornby H.S., Oxford Advanced: Dictionary of Current English, Britain: Oxford University Press, 2010.

Jalaludin Rakhmat, Islam dan Pluralisme Jakarta: Serambi, 2006.

Jhon M. Nainggolan, PAK dalam Masyarakat Majemuk Bandung: Bina Media Informasi, 2009.

Kamus Besar Bahasa Indonesia, Jakarta: Ikhtiar Baru, 1995.

Kamus Besar Bahasa Indonesia Edisi kelima. Jakarta: Kementrian Pendidikan dan Kebudayaan Republik Indonesia, 2016.

Karen Armstrong, Masa Depan Tuhan Bandung: Mizan, 2009.

Leo D. Lefebure, Penyataan Allah, Agama dan Kekerasan Jakarta: BPK Gunung Mulia, 2006

Lucien van Liere, Memutuskan Rantai Kekerasan Jakarta: BPK Gunung Mulia, 2010.

Mery Kolimon dalam Frans Magnis Suseno, Agama Keterbukaan dan Demokrasi Yogyakarta

Paramadina, 2015.

Niels C. Nielsen, Jr, Fundamentalism, Mythos and World Religions New York: State University of New
York, 1993.

Olaf Schuman, Agama-agama Kekerasan dan Perdamaian Jakarta: BPK Gunung Mulia, 2015.

Paul Copan (dkk), Holy War in The Bible USA: Inter Varsity Press, 2011.

Richard M. Daulay, Religion in Politics Jakarta : Libri, 2015.

Samuel P. Huntington, Benturan Antar Peradaban Jakarta: Qalam, 2012.

Sivan E, Friedman M, ed., Religious radicalism and politics in the Middle East New York: State University of New York; 1990.

Sudiaraja A., Agama (di zaman) yang Berubah Yogyakarta: Kanisius, 2006

Sumanto Al Qurtuby, Jihad Melawan Ekstremis Agama, Semarang: Borobudur Indonesia Publishing, 2009.

Syam N., Tantangan multikulturalisme Indonesia: dari radikalisme menuju kebangsaan (Bekasi:Kanisius, 2009

Thomas H. Groome, Christian Religious Education, Jakarta: BPK Gunung Mulia, 2011.

Timmerman C, Hutsebaut D, Mels S, Nonneman W, Van Herck W, ed. Faith-based radicalism: christianity, islam, and judaism between constructive activism and destructive fanaticism Brussels: Peter Lang, 2007.

Umar ARM. Melacak akar radikalisme di Indonesia Jakarta: Ilmu Sosial dan Ilmu Politik. 2010.

Van Hoeve, Ensiklopedi Indonesia, Jakarta: Ikhtiar Baru, 1984.

Weinata Sairin, Visi Gereja Memasuki Milenium Baru Jakarta: BPKGunung Mulia, 2002.

Yusuf Qardhawi, Islam Radikal: Analisis terhadap Radikalisme dalam berislam dan upaya pemecahannya, (Solo: Era Intermedia, 2000/ 
https://www.gmim.or.id/mtpj

http://www.leimena.org/id/page/v/8/instit ut-leimena.

http://m.satuharapan.com/index.php?id=1 48\&tx_ttnews[tt_news)

http://alkitab.sabda.org/passage.php?pass age $=$ lukas $\% 206: 27-36 \&$ mode $=$ text

http://alkitab.sabda.org/passage.php?pass age=MAT.\%2022:37-

$39 \&$ mode $=$ text

http://sinta.ukdw.ac.id/sinta/resources/sin tasrv/nim/01021871

https://books.google.co.id/books?hl

https://kbbi.web.id/radikalisme

https://www.theguardian.com/commentis free/2014/jan/20/we-need-radicalsfor- social-change

http://www.encyclopedia.com/philosophy -and religion/philosophy/philosophyterms-and-concepts/radicalism

https://tirto.id/selamat-tinggal-generasimilenial-selamat-datang-generasi-zcnzX

https://www.kompasiana.com/teruntukgenerasi-muda-bangsa

https://nasional.tempo.comuda/read/8745 37/media-massa-diajak-tangkalpaham-radikalisme-dan-terorisme

https://nasional.sindonews.com/read/1107 997/14/sejarah-munculnyaradikalisme-1463048982 (diakses pada tanggal 21 April 2016)

http://www.nu.or.id/post/read/78246/radi kalisme-agama-di-indonesia http://lib.ui.ac.id/file?file=digital/203022 92-T30635\%20-

\%20Radikalisme\%20kelompok.pdf

https://nasional.sindonews.com/read/1107 997/14/sejarah-munculnyaradikalisme-1463048982

https://nasional.sindonews.com/read/1107 997/14/sejarah-munculnyaradikalisme-1463048982

http://nasional.kompas.com/read/2017/03 /15/14090061/bin.menguatnya.kelo mpok.radikal.keagamaan.jadi.penye bab.konflik.sosial

https://almanhaj.or.id/4120-radikalismesebab-dan-terapinya

https://epthinktank.eu/2016/07/12/radicali sation-extremism-and-terrorismwords-matter/

https://id:Wikipedia.org/wiki/Anarkisme\# Anarkisme.dan.kekerasan

http://www.leimena.org/id/page/v/8/instit ut-leimena.

http://m.satuharapan.com/index.php?id=1 48\&tx_ttnews[tt_news),

http://www.fsh.unsiq.ac.id/wpcontent/uploads/2017/10/PDF3.pdf.

http://www.teenink.org/nonfiction/acade mic/article/297208/ReligiousRadicalism/ 